Prepared in cooperation with Department of the Navy, Naval Facilities Engineering Command, Northwest

\title{
Selected Natural Attenuation Monitoring Data, Operable Unit 1, Naval Undersea Warfare Center, Division Keyport, Washington, June 2005
}

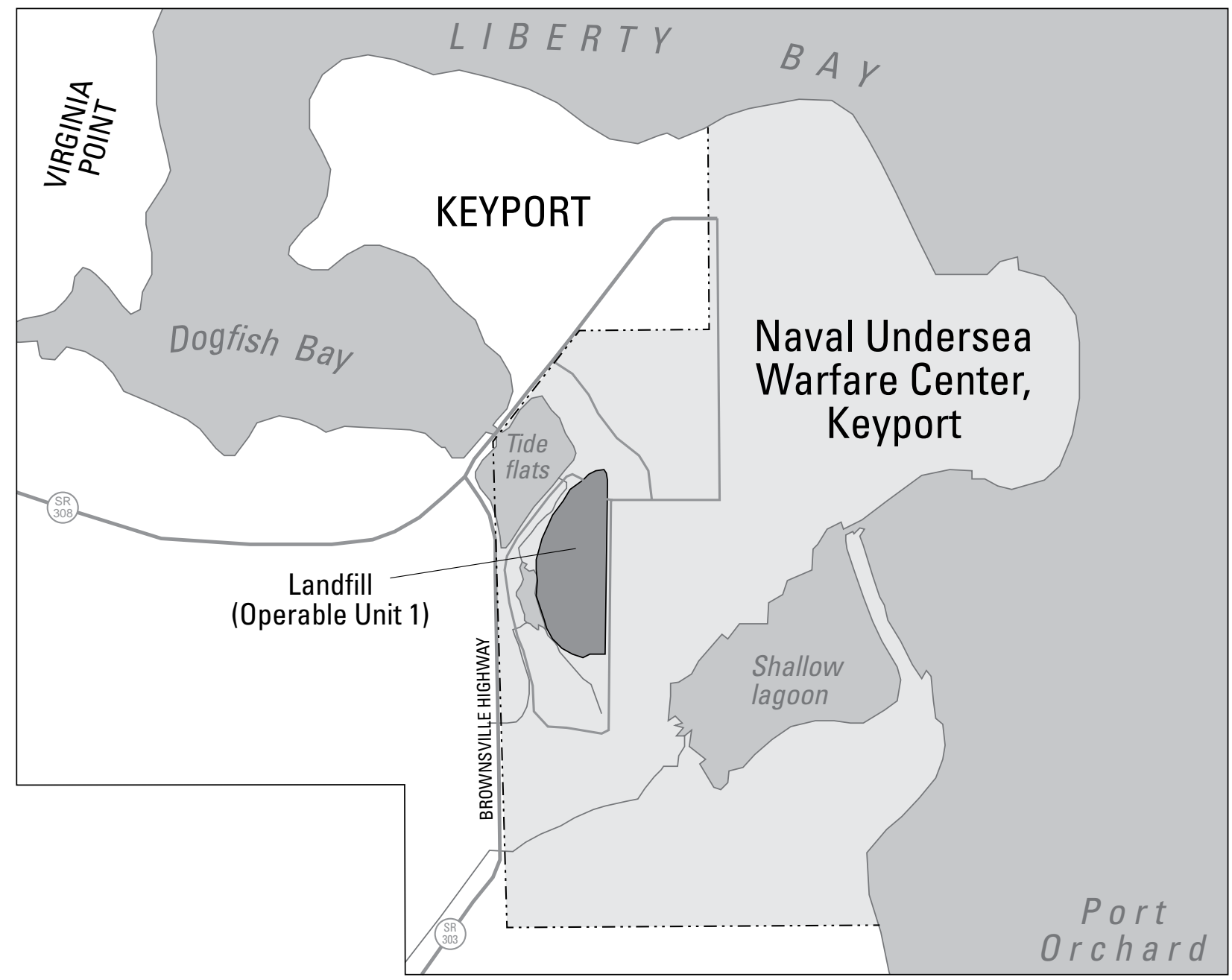

Open-File Report 2006-1374 



\section{Selected Natural Attenuation Monitoring Data, Operable Unit 1, Naval Undersea Warfare Center, Division Keyport, Washington, June 2005}

By R.S. Dinicola and R.L. Huffman

Prepared in cooperation with

Department of the Navy, Naval Facilities Engineering Command, Northwest

Open-File Report 2006-1374 


\title{
U.S. Department of the Interior DIRK KEMPTHORNE, Secretary
}

\author{
U.S. Geological Survey \\ Mark D. Myers, Director
}

\section{U.S. Geological Survey, Reston, Virginia: 2006}

For product and ordering information:

World Wide Web: http://www.usgs.gov/pubprod

Telephone: 1-888-ASK-USGS

For more information on the USGS--the Federal source for science about the Earth, its natural and living resources, natural hazards, and the environment:

World Wide Web: http://www.usgs.gov

Telephone: 1-888-ASK-USGS

Any use of trade, product, or firm names is for descriptive purposes only and does not imply endorsement by the U.S. Government.

Although this report is in the public domain, permission must be secured from the individual copyright owners to reproduce any copyrighted materials contained within this report.

Suggested citation:

Dinicola, R.S., and Huffman, R.L., 2006, Selected natural attenuation monitoring data, Operable Unit 1, Naval Undersea Warfare Center, Division Keyport, Washington, June 2005: U.S. Geological Survey Open-File Report 2006-1374, 28 p. 


\section{Contents}

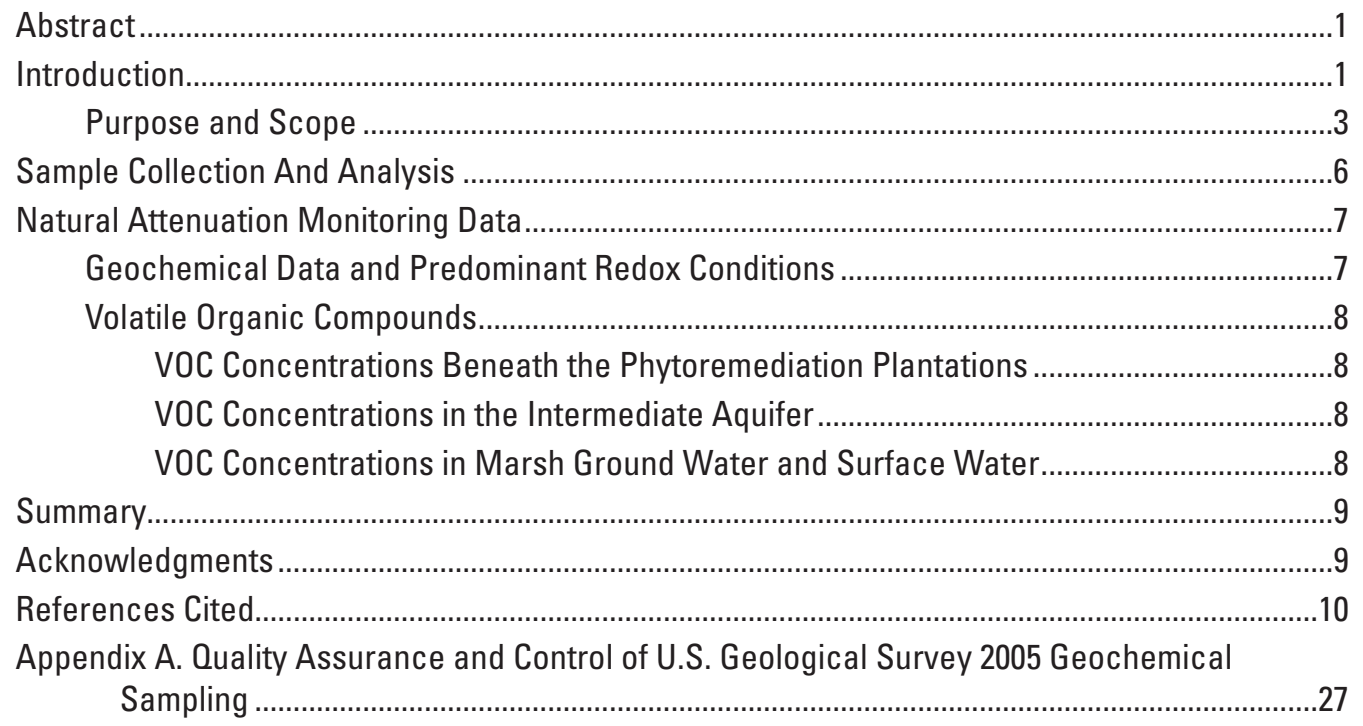

\section{Figures}

Figure 1. Map showing location of the Operable Unit 1 study area, Naval Undersea Warfare Center, Division Keyport, Washington ...............................

Figure 2. Map showing Llocation of former landfill, two phytoremediation plantations, and data collection sites at Operable Unit 1, Naval Undersea Warfare Center (NUWC), Division Keyport, Washington

\section{Tables}

Table 1. Wells and piezometers sampled and water levels measured at Operable Unit 1, Naval Undersea Warfare Center, Division Keyport, Washington, June 2005....... 5

Table 2. Predominant redox conditions at wells and piezometers, and ground-water geochemical data collected at Operable Unit 1, Naval Undersea Warfare Center, Division Keyport, Washington, 1996 to 2005

Table 3. Concentrations of selected volatile organic compounds in ground-water samples from monitoring wells, piezometers, and diffusion samplers, and in surface-water samples from the marsh stream collected by the USGS from 1999 to 2005 at Operable Unit 1, Naval Undersea Warfare Center, Division Keyport, Washington 


\section{Conversion Factors, Datums, and Abbreviations and Acronyms}

Conversion Factors

\begin{tabular}{lcl}
\hline Multiply & By & To obtain \\
\hline acre & 4,047 & square meter \\
acre & 0.4047 & hectare \\
foot (ft) & 0.3048 & meter \\
inch (in) & 2.54 & centimeter \\
mile (mi) & 1.609 & kilometer \\
\hline
\end{tabular}

Temperature in degrees Celsius $\left({ }^{\circ} \mathrm{C}\right)$ may be converted to degrees Fahrenheit $\left({ }^{\circ} \mathrm{F}\right)$ as follows:

$$
{ }^{\circ} \mathrm{F}=\left(1.8 \times{ }^{\circ} \mathrm{C}\right)+32
$$

Temperature in degrees Fahrenheit $\left({ }^{\circ} \mathrm{F}\right)$ may be converted to degrees Celsius $\left({ }^{\circ} \mathrm{C}\right)$ as follows:

$$
{ }^{\circ} \mathrm{C}=\left({ }^{\circ} \mathrm{F}-32\right) / 1.8
$$

Datums

Vertical coordinate information is referenced to North American Vertical Datum of 1988 (NAVD 88).

Horizontal coordinate information is referenced to North American Datum of 1927 (NAD 27).

Altitude, as used in this report, refers to distance above the vertical datum.

Abbreviations and Acronyms

\begin{tabular}{ll}
\hline $\begin{array}{l}\text { Abbreviations and } \\
\text { Acronyms }\end{array}$ & Meaning \\
\hline 1,1-DCA & 1,1-dichloroethane \\
$1,2-D C A$ & 1,2 -dichloroethane \\
$1,1-D C E$ & 1,1 -dichloroethene \\
CA & chloroethane \\
cis-DCE & cis-1,2-dichloroethene \\
CVOC & chlorinated volatile organic compound \\
DO & dissolved oxygen \\
ml & mililiter \\
NUWC & Naval Undersea Warfare Center \\
NWQL & USGS National Water Quality Laboratory \\
ORP & oxidation-reduction potential \\
OU-1 & Operable Unit 1 \\
STL & Severn Trent Laboratories \\
TCA & $1,1,1,-$ trichloroethane \\
TCE & trichloroethene \\
USEPA & U.S. Environmental Protection Agency \\
USGS & U.S. Geological Survey \\
VC & vinyl chloride \\
VOC & volatile organic compound \\
\hline
\end{tabular}




\title{
Selected Natural Attenuation Monitoring Data, Operable Unit 1, Naval Undersea Warfare Center, Division Keyport, Washington, June 2005
}

\author{
By R.S. Dinicola and R.L. Huffman
}

\section{Abstract}

Previous investigations have shown that natural attenuation and biodegradation of chlorinated volatile organic compounds (VOCs) are substantial in shallow ground water beneath the 9-acre former landfill at Operable Unit 1 (OU-1), Naval Undersea Warfare Center, Division Keyport, Washington. The U.S. Geological Survey (USGS) has continued to monitor ground-water geochemistry to assure that conditions remain favorable for contaminant biodegradation. This report presents the ground-water geochemical and selected VOC data collected at OU-1 by the USGS during June 21-24, 2005, in support of long-term monitoring for natural attenuation.

For June 2005, the strongly reducing conditions (sulfate reduction and methanogenesis) most favorable for reductive dechlorination of chlorinated VOCs were detected in fewer upper-aquifer wells than were detected during 2004. Redox conditions in ground water from the intermediate aquifer just downgradient of the landfill remained somewhat favorable for reductive dechlorination. Overall, the changes in redox conditions observed at individual wells have not been consistent or substantial throughout either the upper or the intermediate aquifers.

In apparent contrast to changes in redox conditions, the chlorinated VOC concentrations were lower than previously measured in many of the piezometers in the northern phytoremediation plantation. The decrease in contaminant concentrations beneath the northern plantation and the end-product (ethane and ethene) evidence for reductive dechlorination are consistent with 2000-04 results.

In the southern phytoremediation plantation, changes in chlorinated VOC concentrations were variable. Most notable was a substantial decrease in the sum of trichloroethene, cis-1,2-dichloroethene, and vinyl chloride concentrations at piezometer P1-9 from 75,000 to 1,000 micrograms per liter between 2004 and 2005. The high concentrations of the reductive dechlorination end-products ethane and ethene measured at the most contaminated sites (P1-6 and P1-7), as well as measurable concentrations at sites P1-9 and P1-10, are reliable evidence that reductive dechlorination of chlorinated VOCs is ongoing in the southern plantation.

In the 10 passive-diffusion samplers deployed beneath the marsh stream, the highest chlorinated VOC concentrations measured were at a site (S-4) about midway along the sampled stream reach. In 2005, the sum of trichloroethene, cis-1,2dichloroethene, and vinyl chloride concentrations increased nearly twofold in comparison to 2004. It is not certain that the apparent increase in concentrations is representative of site conditions. However, the chlorinated VOC concentrations have increased each time at the two most contaminated passivediffusion sampler sites that have been sampled for multiple years. In the marsh stream, chlorinated VOC concentrations in surface water were low at the site (SW-S6) near the upgradient margin of the former landfill. Concentrations in the stream increased substantially after flowing past the southern phytoremediation plantation to the downstream site (MA-12).

Overall, the 2005 data were consistent with previous findings of continued biodegradation of chlorinated VOCs in ground water, along with continued discharge of some chlorinated VOCs to surface water in the marsh stream.

\section{Introduction}

Chlorinated volatile organic compounds (VOCs) have migrated to ground water beneath the 9-acre former landfill at Operable Unit 1 (OU-1) at the Naval Undersea Warfare Center (NUWC), Division Keyport. The NUWC is on a small peninsula in Kitsap County, Washington, in an extension of Puget Sound called Liberty Bay (fig. 1). The 9-acre former landfill at OU-1 is on the narrow strip of land connecting the peninsula to the mainland and is adjacent to tidal flats that are an extension of Dogfish and Liberty Bays. The OU-1 landfill is unlined at the bottom and was constructed in a former marshland. The landfill was the primary disposal area for domestic and industrial wastes generated by NUWC Keyport from the 1930s through 1973. Paints, thinners, solvents, 


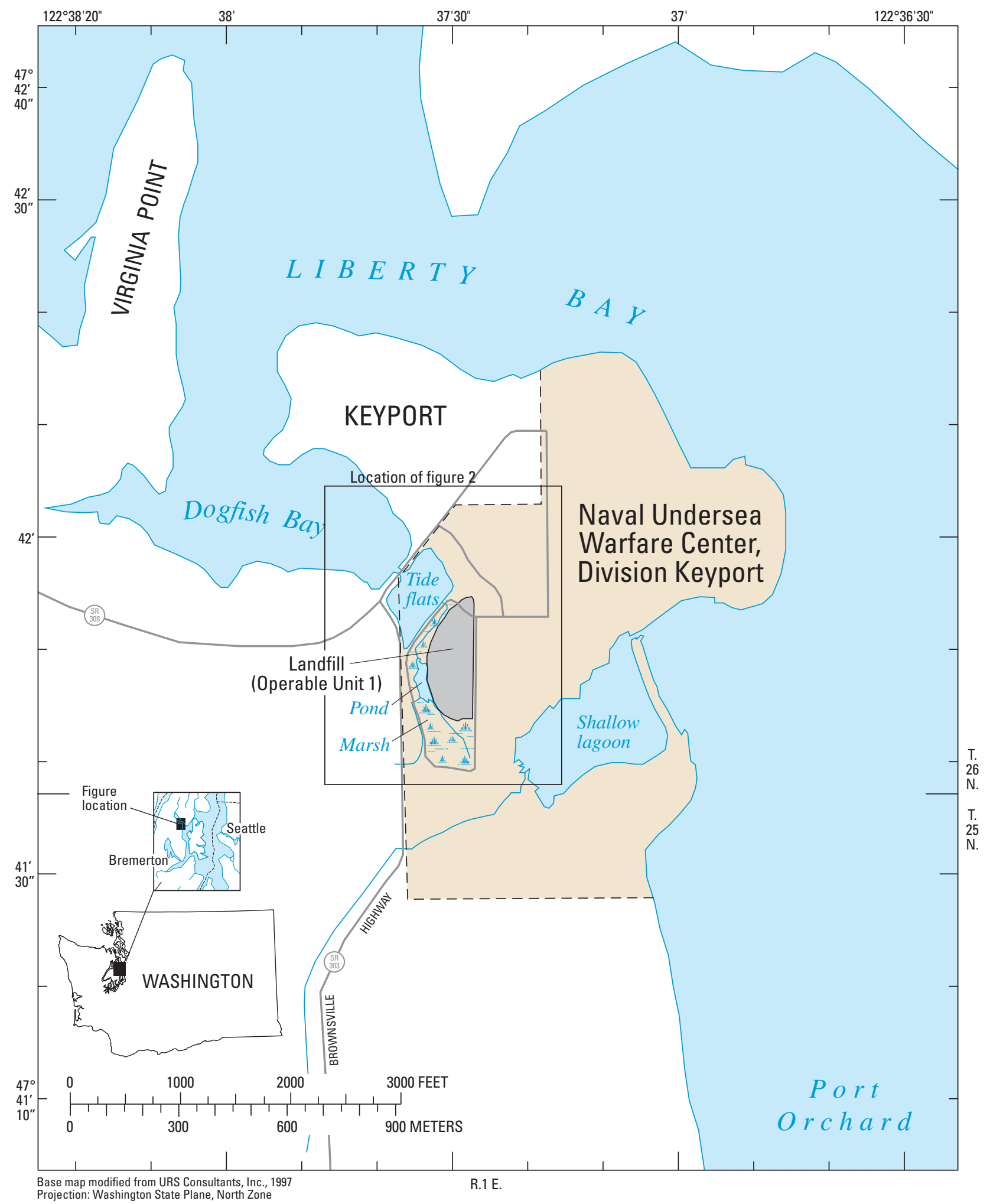

Figure 1. Location of the Operable Unit 1 study area, Naval Undersea Warfare Center, Division Keyport, Washington. 
acids, dried sludge from a wastewater-treatment plant, and other industrial wastes were disposed in the landfill. The most concentrated disposal area for waste paints and solvents was at the southern end of the landfill.

Chlorinated VOCs are present in the upper and intermediate aquifers and in surface water at OU-1. Ground water beneath OU-1 occurs within a series of aquifers that are composed of permeable sand, gravel, or fill materials separated by finer-grained silt or clay layers. Contamination at OU-1 is known to occur only in about the top 60 feet of the unconsolidated deposits in the hydrogeologic units referred to as the unsaturated zone, the upper aquifer, the middle aquitard, and the intermediate aquifer. Ground water in the unconfined upper aquifer generally flows from east to west towards Dogfish Bay. Ground water in the predominately confined intermediate aquifer flows from the south and west towards the landfill, and then northwest from the landfill towards Dogfish Bay (Dinicola and others, 2002). Two perennial freshwater creeks drain the marsh adjacent to the landfill and discharge into the tideflats of Dogfish Bay.

The predominant contaminants in ground water beneath OU-1 are trichloroethene (TCE) and its degradation byproducts cis-1,2-dichloroethene (cis-DCE) and vinyl chloride (VC). The compound 1,1,1-trichloroethane (TCA) and its degradation byproducts 1,1-dichloroethane (1,1-DCA), 1,1-dichloroethene (1,1-DCE), and chloroethane (CA) have been detected at concentrations of concern at a few locations at OU-1. A need for remedial action was identified because those hazardous compounds present a potential risk to humans (URS Consultants, Inc., 1998). Phytoremediation combined with on-going natural attenuation processes was chosen by the Navy as the preferred remedy (URS Consultants, Inc., 1998). The Navy planted two hybrid poplar plantations on the landfill (fig. 2) in spring of 1999 to remove and control the migration of chlorinated VOCs in shallow ground water (URS Greiner, Inc., 1999). The landfill between the plantations is covered with pavement, although the area north of the northern plantation is permeable.

\section{Purpose and Scope}

The Navy began a cooperative effort with the U.S. Geological Survey (USGS) in 1995 to investigate various natural attenuation mechanisms at OU-1. Field and laboratory studies conducted from 1996 through 2000 showed that natural attenuation and biodegradation of chlorinated VOCs in shallow ground water at OU-1 were substantial (URS Consultants, Inc., 1997; Bradley and others, 1998; Dinicola and others, 2002). The USGS has continued to monitor the geochemistry of ground water to assure that conditions remain favorable for contaminant biodegradation, and annual monitoring from 2001 through 2004 confirmed that biodegradation was continuing (Dinicola, 2006).

This report presents ground-water chemical and selected VOC data collected by the USGS at OU-1 during June 21-24, 2005 , in support of the long-term monitoring for natural attenuation. USGS data collected from 1996 through 2004 were presented in Dinicola and others (2002), Dinicola (2003, 2004, 2006), and, Dinicola and Huffman (2004). In June 2005, the USGS collected ground-water samples from 13 wells and 9 piezometers (table 1 and fig. 2). Concentrations of various geochemical constituents used to evaluate ground-water redox conditions were determined in all samples from wells and piezometers. Concentrations of VOCs also were determined by the USGS in samples from all piezometers and in samples from 3 of the 13 monitoring wells. The Navy determined VOC concentrations in samples they collected from other OU-1 monitoring wells during April 2005, but those data are not presented in this report. The USGS determined VOC concentrations in shallow ground water directly beneath the southern reach of the marsh stream (fig. 2) using passivediffusion samplers. Samplers were located closer together than previously done to refine the characterization of contaminant discharge to surface water. The USGS also determined VOC concentrations in surface-water samples collected at the upstream and downstream ends of the reach of the marsh creek where diffusion samplers were deployed. 


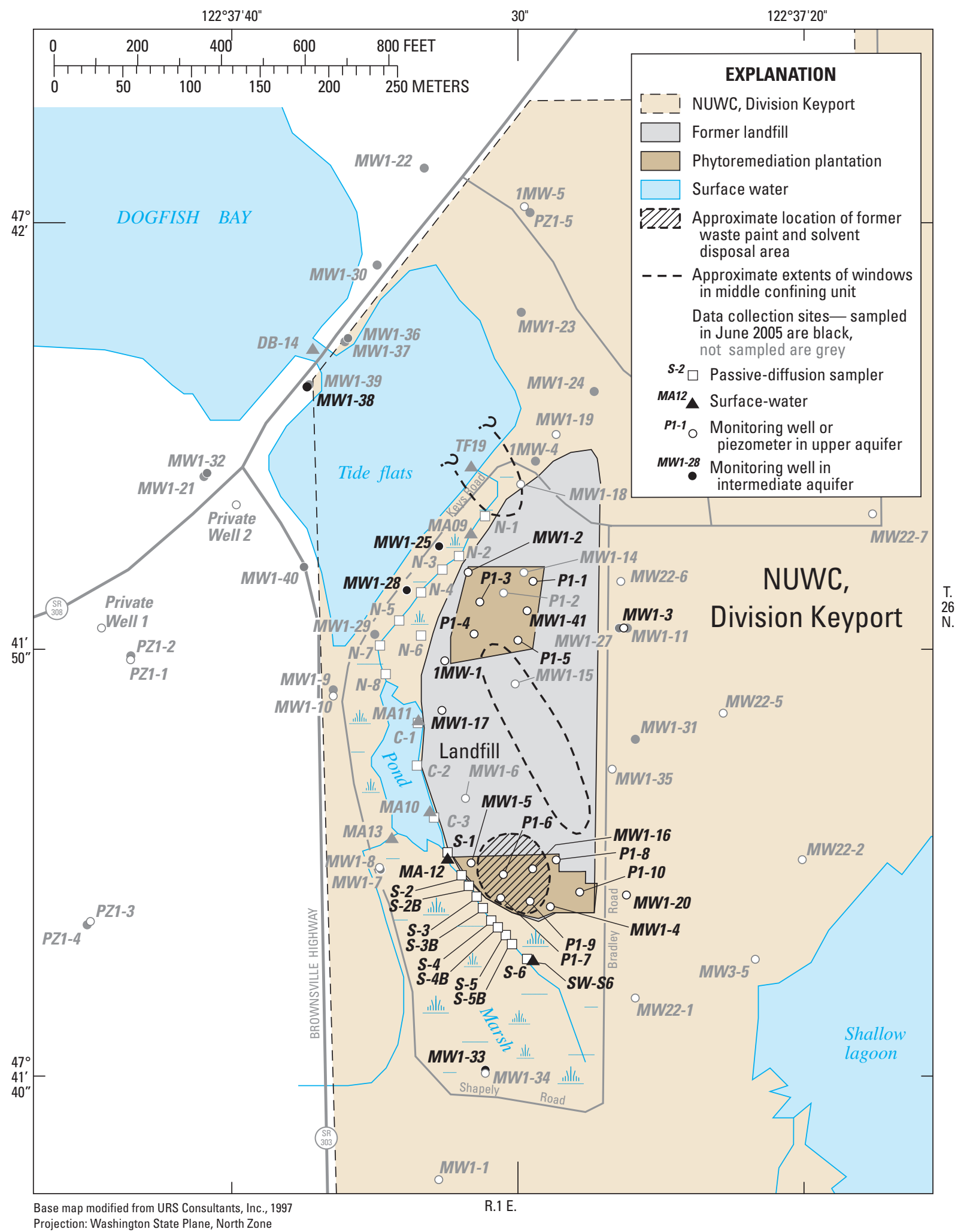

Figure 2. Location of former landfill, two phytoremediation plantations, and data collection sites at Operable Unit 1, Naval Undersea Warfare Center (NUWC), Division Keyport, Washington. 
Table 1. Wells and piezometers sampled and water levels measured at Operable Unit 1, Naval Undersea Warfare Center, Division Keyport, Washington, June 2005.

[Study site No.: MW, monitoring well; P, piezometer; USGS site No.: Unique number for each site based on latitude and longitude of the site. First six digits are latitude, next seven digits are longitude, and final two digits are a sequence number to uniquely identify each site. Altitudes of water levels and measuring points are given in feet above or below (-) NAVD88. Water level is in feet below measuring point (bmp). Depth of well and screened interval are in feet below land surface. Measuring point: Water levels in wells are usually reported as depths below land surface, although the measuring point can be any convenient fixed place near the top of the well. For these wells and piezometers, the measuring points are marked points on the tops of well casings-they vary from being near the land surface to a few feet above land surface. The altitude of the measuring point is commonly recorded so that static water levels also can be reported as altitudes; VOCs sampled by USGS: Y, yes, N, no. Abbreviations: USGS, U.S. Geological Survey; VOC, volatile organic compounds; ft, foot; ft bmp, foot below measuring point; in., inch]

\begin{tabular}{|c|c|c|c|c|c|c|c|c|c|c|}
\hline $\begin{array}{c}\begin{array}{c}\text { Study site } \\
\text { No. }\end{array} \\
1 \mathrm{MW}-1\end{array}$ & $\begin{array}{c}\text { USGS site No. } \\
474151122373201\end{array}$ & \multicolumn{2}{|c|}{$\begin{array}{l}\text { Date and time } \\
\text { measured }\end{array}$} & 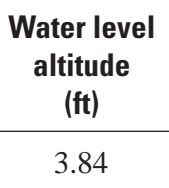 & $\begin{array}{c}\begin{array}{c}\text { Water } \\
\text { level } \\
\text { (ft bmp) }\end{array} \\
6.22\end{array}$ & $\begin{array}{c}\begin{array}{c}\text { Altitude of } \\
\text { measuring } \\
\text { point (ft) }\end{array} \\
10.06\end{array}$ & $\begin{array}{c}\begin{array}{c}\text { Depth of } \\
\text { well } \\
\text { (ft) }\end{array} \\
16.5\end{array}$ & $\begin{array}{c}\begin{array}{c}\text { Casing } \\
\text { diameter } \\
\text { (in.) }\end{array} \\
2\end{array}$ & $\begin{array}{c}\begin{array}{c}\text { Screened } \\
\text { interval } \\
\text { (ft) }\end{array} \\
5.5-15.5\end{array}$ & $\begin{array}{c}\text { VOCs } \\
\text { sampled by } \\
\text { USGS }\end{array}$ \\
\hline MW1-2 & 474153122373101 & $06-22-05$ & $12: 40$ & 2.35 & 9.54 & 11.89 & 18.5 & 4 & $12.5-17.5$ & $\mathrm{~N}$ \\
\hline MW1-3 & 474152122372501 & $06-20-05$ & 13:00 & 10.13 & 3.42 & 13.55 & 11.5 & 4 & $5.5-10.5$ & $\mathrm{~N}$ \\
\hline MW1-16 & 474146122372801 & $06-23-05$ & 11:00 & 5.69 & 7.14 & 12.83 & 12.0 & 2 & $6-11$ & $\mathrm{~N}$ \\
\hline MW1-17 & 474150122373201 & $06-20-05$ & $15: 00$ & 6.72 & 5.22 & 11.94 & 13.5 & 2 & $7.5-12.5$ & $\mathrm{~N}$ \\
\hline MW1-20 & 474145122372501 & $06-20-05$ & $11: 45$ & 6.74 & 3.70 & 10.44 & 16.0 & 2 & $10-15$ & $\mathrm{~N}$ \\
\hline MW1-25 & 474154122373201 & $06-21-05$ & $12: 15$ & 1.75 & 10.16 & 11.91 & 49.0 & 2 & $38-48$ & $\mathrm{Y}$ \\
\hline $\begin{array}{l}\text { MW1-41 } \\
\text { (duplicate) } \\
\text { (blank) }\end{array}$ & 474152122372901 & 06-20-05 & $\begin{array}{l}15: 30 \\
12: 01 \\
15: 05\end{array}$ & 6.85 & 8.36 & 15.27 & 15.0 & 2 & $5-15$ & $\mathrm{~N}$ \\
\hline P1-1 & 474153122372801 & $06-22-05$ & $12: 15$ & 6.41 & 7.95 & 14.36 & 15.0 & 1 & $10-15$ & $\mathrm{Y}$ \\
\hline $\begin{array}{l}\text { P1-3 } \\
\text { (duplicate) }\end{array}$ & 474153122373102 & $06-22-05$ & $\begin{array}{l}11: 15 \\
11: 16\end{array}$ & 3.46 & 9.33 & 12.79 & 15.0 & 1 & $10-15$ & $\mathrm{Y}$ \\
\hline P1-4 & 474152122373101 & $06-21-05$ & $15: 00$ & 4.44 & 8.81 & 12.55 & 15.0 & 1 & $10-15$ & $\mathrm{Y}$ \\
\hline P1-5 & 474152122372801 & $06-21-05$ & $15: 20$ & 6.23 & 8.83 & 15.06 & 15.0 & 1 & $10-15$ & $\mathrm{Y}$ \\
\hline P1-6 & 474146122373001 & $06-22-05$ & $14: 30$ & 5.54 & 7.22 & 12.76 & 15.0 & 1 & $10-15$ & $\mathrm{Y}$ \\
\hline
\end{tabular}




\section{Sample Collection And Analysis}

Water-level measurements, sample collection and processing, and field analyses were in accordance with applicable USGS procedures (U.S. Geological Survey, 19972005), except that samples were collected using a peristaltic pump. Geochemical measurements and concentrations determined for samples from 13 wells and 9 piezometers included dissolved hydrogen $\left(\mathrm{H}_{2}\right)$, dissolved oxygen (DO), filtered organic carbon, filtered nitrate plus nitrite, filtered manganese, filtered iron (II), filtered sulfate, unfiltered sulfide, dissolved methane, dissolved carbon dioxide, $\mathrm{pH}$, specific conductance, oxidation-reduction potential (ORP), and filtered chloride. Concentrations of 64 volatile organic compounds (VOCs) were determined for samples from 3 of the 13 wells, from all 9 piezometers, and from all of the passive-diffusion samplers that were deployed. The concentrations of the dissolved gasses ethane, ethene, and methane were also determined for samples from three wells, from all piezometers, and from all of the diffusion samplers.

After measuring depth to water, all well and piezometer samples were collected with a peristaltic pump and single-use polyurethane tubing. A stainless-steel weight was attached to the bottom of the tubing to accurately collect the sample from the mid-screen elevation in each well. Samples were collected after approximately three casing-volumes of water were purged from the wells and after allowing $\mathrm{pH}$, specific conductance, and DO to stabilize within 0.1 units, 5 percent, and $0.3 \mathrm{mg} / \mathrm{L}$, respectively. Those three analytes and ORP were measured in a flow-through chamber using temperature compensated probes from a YSI ${ }^{\mathrm{TM}}$ data sonde. The specific conductance probe was checked daily with standard reference solutions; the $\mathrm{pH}$ probe was calibrated daily with two $\mathrm{pH}$ standards; and the dissolved-oxygen probe was calibrated daily using the water-saturated air method and occasionally verified with zero dissolved-oxygen solution. Dissolvedoxygen analyses were confirmed for most samples using 0 to $1 \mathrm{mg} / \mathrm{L}$ CHEMets Rhodazine- $\mathrm{D}^{\mathrm{TM}}$ colorimetric ampoules (manufactured by CHEMetrics, Inc., Calverton, Virginia). These ampoules were filled directly from the sampling tube after well purging was complete.

Concentrations of iron (II) were measured in the field in a sample filtered through a $0.45-\mu \mathrm{m}$ membrane filter using a colorimetric 1,10 phenanthroline indicator method and a Hach Model 2010 spectrophotometer following Hach Method 8146 [Hach Company, 1998; adapted from America Public Health Association (1980)]. Sulfide concentrations were measured in the field using a colorimetric methylene-blue indicator method immediately using the same spectrophotometer according to Hach Method 81360 [Hach Company, 1998; procedure is equivalent to U.S. Environmental Protection Agency (USEPA) method 376.2 U.S. Environmental Protection Agency (1983)]. Information about the methodologies used to determine iron and sulfide concentrations is described at http://www.hach.

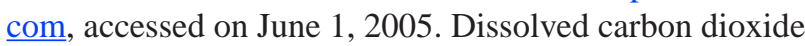
$\left(\mathrm{CO}_{2}\right)$ concentrations were measured in the field with Titret ${ }^{\circ}$ Sodium hydroxide titrant with a $\mathrm{pH}$ indicator (manufactured by CHEMetrics, Inc., Calverton, Virginia).

Dissolved $\mathrm{H}_{2}$ in ground water was sampled using the bubble-strip method of Chapelle and others (1997) and concentrations were measured in the field using a gas chromatograph equipped with a reduction gas detector. Initial gas samples from each well were collected and analyzed after at least 20 minutes of stripping; subsequent samples were collected and analyzed at about 5-minute intervals until consecutive $\mathrm{H}_{2}$ concentrations stabilized to within 10 percent, a process that often required an hour or more.

Samples for determination of nitrate plus nitrite, manganese, sulfate, and chloride concentrations were filtered through a $0.45-\mu \mathrm{m}$ membrane filter into polyethylene bottles, chilled, and sent to the USGS National Water Quality Laboratory (NWQL) in Lakewood, Colorado. Manganese samples were acidified in the field with nitric acid to a $\mathrm{pH}$ of less than 2, and then analyzed at NWQL by inductively coupled plasma as described by Fishman (1993). Chloride and sulfate were analyzed using ion chromatography as described by Fishman and Friedman (1989). Nitrate plus nitrite were analyzed colorimetrically by cadmium reduction and diazotization as described by Fishman (1993). The results for the nitrate plus nitrite analyses are referred to simply as nitrate in this report because nitrite was not detected at the site (Dinicola and others, 2002).

Samples for dissolved organic carbon analysis were filtered through a $0.45-\mu \mathrm{m}$ filter, collected in amber glass bottles, acidified in the field with sulfuric acid to a $\mathrm{pH}$ of less than 2, chilled to less than $4^{\circ} \mathrm{C}$, and shipped to the NWQL. Organic carbon concentrations were determined using persulfate oxidation as described by Brenton and Arnett (1993).

Samples for VOC analysis were collected in pre-acidified 40-mL glass vials, placed on ice, and shipped to the NWQL for subsequent analysis at Severn Trent Laboratories (STL) in Denver, Colorado, using purge and trap capillary-column gas chromatography/mass spectrometry (USEPA Method SW846 8260B; accessed November 2005 at http://www.epa.gov/ epaoswer/hazwaste/test/pdfs/8260b.pdf). Samples for analysis of ethane, ethene, and methane were collected in pre-acidified 40-mL glass vials, placed on ice, and shipped to the NWQL for subsequent analysis at Severn Trent Laboratories (STL) in Denver, Colorado, using gas chromatography with a flameionization detector (U.S. Environmental Protection Agency Method RSK SOP-175; Kampbell and Vandegrift, 1998).

VOCs in shallow ground-water directly beneath the marsh stream were determined at 10 locations using passivediffusion samplers, and VOCs in surface water in the marsh stream were determined from grab samples from 2 locations (fig. 2). Ground-water samples were collected using passive-diffusion samplers deployed along an approximate 
320 - $\mathrm{ft}$ reach of the marsh stream adjacent to the southern phytoremediation plantation, and surface-water grab samples were collected from the marsh stream at the upstream and the downstream ends of the reach. The most downstream passivediffusion sampler site (S-1) was located at the pre-existing MA-12 surface-water sampling site. The most upstream passive-diffusion sampler site (S-6) was located at the newly established SW-S6 surface-water sampling site. The eight additional passive-diffusion samplers were distributed about evenly along the length of the stream reach. Six sites (S-1, S-2, S-3, S-4, S-5, and S-6) were sampled in previous years, and four sites (S-2B, S-3B, S-4B, and S-5B) were newly established. The diffusion samplers were constructed by the USGS in Tacoma, Washington, and consisted of 8-in.-long by 2 -in.-diameter polyethylene lay-flat tubing that was filled with deionized water and heat sealed at both ends. The filled bags were inserted into plastic mesh sleeves to protect them from damage, and were buried by hand in about $12 \mathrm{in.} \mathrm{of}$ mud beneath the marsh creek. The holes were backfilled with native materials and tamped down and left to equilibrate with pore water for more than 2 weeks. The locations of the samplers were marked with wooden stakes and approximately located on a site map. Samplers were retrieved by hand and immediately processed. A corner of each bag was cut and three pre-acidified 40-mL glass VOC vials were filled, sealed, and kept on ice for shipment to NWQL for VOC analysis at STL using purge and trap capillary-column gas chromatography/mass spectrometry (USEPA Method SW846 8260B), and for ethane, ethene, and methane analysis using gas chromatography with a flame-ionization detector (USEPA Method RSK SOP-175). Surface water was sampled at sites MA-12 and SW-S6 by filling a polyethylene bottle from mid depth in the center of the marsh stream. The sample was immediately poured into three pre-acidified $40-\mathrm{mL}$ glass VOC vials, sealed, and kept on ice for shipment to NWQL for VOC analysis at STL using the same methods.

Quality assurance and control of geochemical and contaminant sampling included collecting two duplicate samples for selected redox-sensitive analytes and VOCs and analyzing one field blank sample for VOCs. No substantial quality issues were identified in those samples (appendix A).

\section{Natural Attenuation Monitoring Data}

Ground-water chemistry data collected by the USGS at OU-1 during June 2005 in support of long-term monitoring for natural attenuation are summarized in this section. The June 2005 data include concentrations of redox-sensitive geochemical constituents at 12 wells and 9 piezometers, and concentrations of VOCs at 9 piezometers, 3 intermediate aquifer wells, 10 passive-diffusion sampler sites beneath the marsh stream adjacent to the southern plantation, and 2 surface-water sites in the marsh stream adjacent to the southern plantation. The geochemical data include concentrations of $\mathrm{H}_{2}$, DO, organic carbon, nitrate plus nitrite, manganese, iron (II), sulfate, sulfide, carbon dioxide, $\mathrm{pH}$, specific conductance, ORP, and chloride. The VOC data include concentrations of a subset of the 64 compounds on Schedule 8260B, and the dissolved gasses ethane, ethene, and methane.

For convenience in following the discussion, the sampled wells and piezometers are grouped with regard to location and aquifer. "Upgradient" sites are the two upper aquifer wells and one intermediate aquifer well upgradient from the landfill. "Northern plantation" and "southern plantation" sites are all upper aquifer wells and piezometers in or near the respective phytoremediation plantations. "Intermediate aquifer" sites are all intermediate aquifer wells downgradient from the landfill; no intermediate aquifer wells are in the footprint of the former landfill.

\section{Geochemical Data and Predominant Redox Conditions}

The June 2005 data and the previous geochemical data collected by USGS at OU-1 (Dinicola and others, 2002; Dinicola, 2003, 2004, and 2006; and Dinicola and Huffman, 2004) are shown in table 2 (at back of report). The predominant redox conditions for June 2005 samples were inferred primarily by dissolved oxygen and dissolved $\mathrm{H}_{2}$ concentrations following guidelines described in Dinicola (2006).

For June 2005, predominant redox conditions in the upgradient wells in the upper aquifer (MW1-3 and MW1-20) were mildly reducing (manganese and iron reduction). These wells have varied between aerobic and sulfate reducing during the past 4 years (table 2). Dissolved organic carbon concentrations have been consistently less than $2 \mathrm{mg} / \mathrm{L}$. Redox conditions in the upgradient well in the intermediate aquifer (MW1-33) have been consistently aerobic.

For June 2005, the strongly reducing conditions (sulfate reduction and methanogenesis) most favorable for reductive dechlorination of chlorinated VOCs were inferred for 6 of 16 upper-aquifer sites in the northern and southern phytoremediation plantations. Mildly reducing conditions (iron or manganese) were detected at the other upper-aquifer sites within the plantations. Methane concentrations of 1.3 to $10 \mathrm{mg} / \mathrm{L}$ were measured at 8 of 9 piezometers in 2005, indicating that methanogenic redox conditions are common, although not predominant, throughout the former landfill. Dissolved organic carbon concentrations, measuring 2.7 to $22 \mathrm{mg} / \mathrm{L}$ in June 2005 , have been consistently greater than those measured in upgradient wells.

Predominant redox conditions in all intermediate aquifer wells downgradient from the landfill have been consistently anaerobic (table 2). Mildly reducing conditions (iron reduction) were inferred for the intermediate aquifer wells at the downgradient margin of the landfill (MW1-25 and MW1-28) and methane concentrations were 1 to $2.1 \mathrm{mg} / \mathrm{L}$. 
Dissolved organic carbon concentrations in these wells (5.9 to $6.3 \mathrm{mg} / \mathrm{L}$ in 2005 ) have been consistently greater than those measured in the upgradient well MW1-33 (0.5 mg/L in 2005).

Measured $\mathrm{H}_{2}$ concentrations generally decreased at OU-1 over the past 5 years, suggesting a trend from strongly- to mildly-reducing predominant redox conditions. However, sulfide and methane concentrations were consistent during that period, indicating persistent sulfate reduction and methanogenesis. Overall, no widespread changes in groundwater redox conditions were measured that could result in either more or less efficient biodegradation of chlorinated VOCs.

\section{Volatile Organic Compounds}

VOC data collected by the USGS from piezometers, selected wells, and passive-diffusion samplers at OU-1 from June 1999 to June 2005 are shown in table 3 (at back of report). The data for wells and piezometers are grouped and presented as described for table 2 , followed by data for marsh passive-diffusion samplers and surface-water grab samples. Complete analytical results for the USGS data for June 2005 and previous years are available from the USGS NWIS web site http://waterdata.usgs.gov/wa/nwis/qwdata, or in Dinicola and others (2002), Dinicola (2003, 2004, and 2006), and Dinicola and Huffman (2004).

\section{VOC Concentrations Beneath the Phytoremediation Plantations}

For the northern plantation in 2005, no TCE, cisDCE, or VC was detected at piezometers P1-1 and P1-5, and chlorinated VOC concentrations at P1-3 and P1-4 were slightly lower than previously measured. The sum of concentrations of the reductive dechlorination end-products ethane and ethene were measured at 74 and $27 \mu \mathrm{g} / \mathrm{L}$ at sites P1-3 and P1-4. The temporal decrease in contaminant concentrations beneath the northern plantation, and the end-products evidence for reductive dechlorination are consistent with 2000-04 results (Dinicola, 2006).

For the southern plantation in 2005, changes in chlorinated VOC concentrations at the piezometers were variable. Most notable was a substantial decrease in total chlorinated VOC concentrations at P1-9 from 75,000 to 1,000 $\mu \mathrm{g} / \mathrm{L}$ between 2004 and 2005. The highest chlorinated VOC concentrations at OU-1 most often were measured at P1-9 in prior years. The reason for the substantial decrease is unknown. Chloride concentration at P1-9 in 2005 (12 mg/L) was about one-half that measured in $2004(26 \mathrm{mg} / \mathrm{L})$ suggesting some dilution, but the possible 2-fold dilution does not explain the 75-fold decrease in chlorinated VOC concentrations. At site P1-10, chlorinated VOC concentrations decreased about 25 percent, a historical low for that site.
The total chlorinated VOC concentrations at P1-7, the most highly contaminated sampling location at OU-1 in 2005, was $92,000 \mu \mathrm{g} / \mathrm{L}$ and consistent with previous levels. Chlorinated VOC concentrations at P1-8 decreased substantially after 2002 , and remained relatively low during 2005 . The total chlorinated VOC concentration increased to $7,600 \mu \mathrm{g} / \mathrm{L}$ during 2005 at one piezometer (P1-6) from the measured historical low of $1,100 \mu \mathrm{g} / \mathrm{L}$ in 2004 , although the 2005 concentration was less than that measured during 1999-2002. The sum of concentrations of the reductive dechlorination end-products ethane and ethene were measured at 620 and $525 \mu \mathrm{g} / \mathrm{L}$ at the most contaminated sites P1-6 and P1-7, respectively, and were estimated at 4 and $10 \mu \mathrm{g} / \mathrm{L}$ at sites P1-9 and P1-10, respectively. Those end-product concentrations are reliable evidence that reductive dechlorination of chlorinated VOCs is ongoing.

\section{VOC Concentrations in the Intermediate Aquifer}

In 2005, chlorinated VOC concentrations measured in the intermediate aquifer near the downgradient margin of the landfill (MW1-25 and MW1-28) were consistent with previous data. The sum of concentrations of the reductive dechlorination end-products ethane and ethene were measured at 19 and $26 \mu \mathrm{g} / \mathrm{L}$ at sites MW1-25 and MW1-28, respectively. Further downgradient in the intermediate aquifer beneath the Highway 308 causeway, well MW1-39 could not be sampled due to recent road work. As in previous years, no VOCs, ethane, or ethene were detected in the adjacent well MW1-38.

\section{VOC Concentrations in Marsh Ground Water and Surface Water}

In 2005 and previous years, the highest chlorinated VOC concentrations measured in the marsh passive-diffusion samplers were at a site (S-4) about mid-way along the sampled stream reach. In 2005, the total chlorinated VOC concentration was $70,000 \mu \mathrm{g} / \mathrm{L}$, which exceeded the previous values of 40,000 and 25,000 $\mu \mathrm{g} / \mathrm{L}$ measured in 2004 and 2000 , respectively. It is not certain that the measured increase in concentrations is representative of site conditions, largely because the passive-diffusion samplers are not deployed in exactly the same location from year to year. However, at the two most contaminated passive-diffusion sampler sites that were sampled three times (S-4 and S-5), the total chlorinated VOC concentrations have increased each time at both sites. In 2005, the second highest chlorinated VOC concentrations were measured at site S-5B (about $75 \mathrm{ft}$ upstream of site S-4), where the total chlorinated VOC concentration was 14,000 $\mu \mathrm{g} / \mathrm{L}$. At sites S-4B and S-5 that are located between the highly contaminated sites S-4 and S-5B, concentrations of chlorinated VOCs were substantially less, indicating a nonuniform pattern of VOC migration towards the marsh creek. 
Chlorinated VOCs were positively detected at all passivediffusion sampler sites, and the reductive dechlorination endproducts ethane and ethene were detected at all sites except S-4B.

In surface water, low concentrations of cis-DCE and VC ( 6.5 and $2.0 \mu \mathrm{g} / \mathrm{L}$, respectively) were measured at the upstream site (SW-S6). At the downstream site (MA-12), the total chlorinated VOC concentration was $830 \mu \mathrm{g} / \mathrm{L}$, similar to that measured by the Navy in 2004 .

\section{Summary}

Previous investigations have shown that natural attenuation and biodegradation of chlorinated VOCs are substantial in shallow ground water beneath the 9-acre former landfill at Operable Unit 1 (OU-1), Naval Undersea Warfare Center (NUWC), Division Keyport, Washington. The U.S. Geological Survey (USGS) has continued to monitor groundwater geochemistry to assure that conditions remain favorable for contaminant biodegradation. This report presents the ground-water geochemical and selected VOC data collected at OU-1 by the USGS during June 21-24, 2005, in support of long-term monitoring for natural attenuation.

The June 2005 data include concentrations of redox-sensitive geochemical constituents at 13 wells and 9 piezometers, and concentrations of VOCs at 9 piezometers, 3 intermediate aquifer wells, 10 passive-diffusion sampler sites beneath the marsh stream adjacent to the southern plantation, and 2 surface-water sites in the marsh stream adjacent to the southern plantation.

For June 2005, the strongly reducing conditions (sulfate reduction and methanogenesis) most favorable for reductive dechlorination of chlorinated VOCs were found in fewer upper-aquifer wells than were found during 2004. Redox conditions in ground water from the intermediate aquifer just down-gradient of the landfill remained somewhat favorable for reductive dechlorination. Measured dissolved $\mathrm{H}_{2}$ concentrations have generally decreased at OU-1 over the past 5 years, suggesting a trend from strongly- to mildly-reducing predominant redox conditions. However, sulfide and methane concentrations were consistent over that period, indicating persistent sulfate reduction and methanogenesis. Overall, the changes in redox conditions measured at individual wells have not been consistent or substantial throughout either the upper or the intermediate aquifers.

In the northern plantation, chlorinated VOC concentrations at P1-3 and P1-4 were lower than previously measured. The decrease in contaminant concentrations beneath the northern plantation, and the positive detection of reductive dechlorination end-products are consistent with 2000-04 results.

In the southern plantation, changes in chlorinated VOC concentrations at the piezometers were variable. Most notable was a substantial decrease in the total chlorinated VOC concentration at P1-9 from 75,000 to $1,000 \mu \mathrm{g} / \mathrm{L}$ between 2004 and 2005. The total chlorinated VOC concentration at the most highly contaminated piezometer at OU-1 (P1-7) in 2005 was $92,000 \mu \mathrm{g} / \mathrm{L}$ and was consistent with previous levels. Chlorinated VOC concentrations at P1-8 decreased substantially after 2002 and remained relatively low during 2005. The high concentrations of the reductive dechlorination end-products ethane and ethene measured at the most contaminated sites (P1-6 and P1-7), as well as measurable concentrations at sites P1-9 and P1-10, are reliable evidence that reductive dechlorination of chlorinated VOCs is ongoing within the southern plantation.

In the 10 passive-diffusion samplers that were deployed beneath the marsh stream, the highest chlorinated VOC concentrations were measured at a site about mid-way along the sampled stream reach (S-4). In 2005, the total chlorinated VOC concentration increased nearly two fold in comparison to 2004. It is not certain that the apparent increase in concentrations is representative of site conditions. However, the chlorinated VOC concentrations have increased each time at the two most contaminated passive-diffusion sampler sites sampled over multiple years. In the marsh stream, chlorinated VOC concentrations in surface water at site SW-S6 near the upgradient margin of the former landfill were low. Concentrations in the stream increased substantially after flowing past the southern phytoremediation plantation to the downstream site (MA-12).

Overall, the 2005 data were consistent with previous findings of continued biodegradation of chlorinated VOCs in ground water, along with continued discharge of some chlorinated VOCs to surface water in the marsh stream.

\section{Acknowledgments}

The authors thank Douglas Thelin of the Naval Facilities Engineering Command, Northwest for his guidance and funding for the continued monitoring. Gene Ellis of NUWC Keyport provided logistic support for field activities. Stephen Cox, Greg Justin, and Karen Payne, of U.S. Geological Survey, Tacoma, Washington, assisted with data collection and analysis. 


\section{References Cited}

American Public Health Association, 1980, Standard methods for the examination of water and wastewater $\left(15^{\text {th }}\right.$ ed.): Washington, D.C., American Public Health Association.

Bradley, P.M., Landmeyer, J.E., and Dinicola, R.S., 1998, Anaerobic oxidation of $\left[1,2-{ }^{14} \mathrm{C}\right]$ dichloroethene under Mn(IV)-reducing conditions: Applied and Environmental Microbiology, v. 64, no. 4, p. 1560-1562.

Brenton, R.W., and Arnett, T.L., 1993, Methods of analysis by the U.S. Geological Survey National Water Quality Laboratory-Determination of dissolved organic carbon by UV-promoted persulfate oxidation and infrared spectrometry: U.S. Geological Survey Open-File Report 92-480, $12 \mathrm{p}$.

Chapelle, F.H., Vroblesky, D.A., Woodward, J.C., and Lovely, D.R., 1997, Practical considerations for measuring hydrogen concentrations in groundwater: Environmental Science and Technology, v. 31, no. 10, p. 2873-2877.

Dinicola, R.S., 2003, Natural attenuation monitoring data during June 2001, Operable Unit 1, Naval Undersea Warfare Center, Division Keyport, Washington: U.S. Geological Survey Open-File Report 03-344, 17 p.

Dinicola, R.S., 2004, Selected natural attenuation monitoring data, Operable Unit 1, Naval Undersea Warfare Center, Division Keyport, Washington: U.S. Geological Survey Open-File Report 2004-1203, 19 p.

Dinicola, R.S., 2006, Continued biodegradation of chloroethene compounds in ground water at Operable Unit 1, Naval Undersea Warfare Center, Division Keyport, Washington: U.S. Geological Survey Scientific Investigations Report 2006-5056, 42 p.

Dinicola, R.S., Cox, S.E., Landmeyer, J.E., and Bradley, P.M., 2002, Natural attenuation of chlorinated volatile organic compounds in ground water at Operable Unit 1, Naval Undersea Weapons Center, Division Keyport, Washington: U.S. Geological Survey Water-Resources Investigations Report 02-4119, 19 p.

Dinicola, R.S., and Huffman, R.L., 2004, Selected natural attenuation monitoring data, Operable Unit 1, Naval Undersea Warfare Center, Division Keyport, Washington, June 2003: U.S. Geological Survey Open-File Report 2004-1330, 19 p.

Fishman, M.J., ed., 1993, Methods of analysis by the U.S. Geological Survey National Water Quality LaboratoryDetermination of inorganic and organic constituents in water and fluvial sediments: U.S. Geological Survey Open-File Report 93-125, 217 p.
Fishman, M.J., and Friedman, L.C., 1989, Methods for determination of inorganic substances in water and fluvial sediments: U.S. Geological Survey Techniques of Water-Resources Investigations, book 5, chap. A1, 545 p.

Hach Company, 1998, DR/2010 Spectrophotometer Procedures Manual: Loveland, Colo., Hach Company, variously paged.

Kampbell, D.H., and Vandergrift, S.A., 1998, Analysis of dissolved methane, ethane, and ethylene in ground water by a standard gas chromatographic technique: Journal of Chromatographic Science, v. 36, p. 253-256.

URS Consultants, Inc., 1997, Final summary data assessment report for Operable Unit 1, Naval Undersea Warfare Center, Division Keyport, Washington: Prepared by URS Consultants, Seattle, Wash., for Engineering Field Activity, Northwest, Naval Facilities Engineering Command, Poulsbo, Wash., 3 v.

URS Consultants, Inc., 1998, Final record of decision for Operable Unit 1, Naval Undersea Warfare Center, Division Keyport, Washington: Prepared by URS Consultants, Seattle, Wash., for Engineering Field Activity, Northwest, Naval Facilities Engineering Command, Poulsbo, Wash., $111 \mathrm{p}$.

URS Greiner, Inc., 1999, Phytoremediation closure report for Operable Unit 1, Naval Undersea Warfare Center, Division Keyport, Washington: Prepared by URS Greiner, Inc., Seattle, Wash., for Engineering Field Activity, Northwest, Naval Facilities Engineering Command, Poulsbo, Wash., variously paged.

U.S. Environmental Protection Agency, 1983, Methods for chemical analysis of water and wastes: Office of Research and Development Report EPA 600/4-79-020, Washington D.C., 552 p.

U.S. Geological Survey, 1997 to 2005, National field manual for the collection of water-quality data: U.S. Geological Survey Techniques of Water-Resources Investigations, book 9, chaps. A1-A9, 2 v., variously paged. [Also available online at http://pubs.water.usgs.gov/twri9A. Chapters originally were published from 1997-1999; updates and revisions are ongoing and are summarized at: http://water. usgs.gov/owq/FieldManual/mastererrata.html] 
Table 2. Predominant redox conditions at wells and piezometers, and ground-water geochemical data collected at Operable Unit 1, Naval Undersea Warfare Center, Division Keyport, Washington, 1996 to 2005.

[Shaded rows indicate newly published data. All other data were published in Dinicola and others (2002), Dinicola (2003), and Dinicola (2004); prior to 2000, bicarbonate was calculated from an unfiltered sample. Reported concentrations less than the detection limit usually are estimated. A range of dissolved hydrogen concentrations are shown when equilibration at a single value was never achieved. Predominant redox conditions: A, aerobic; An, anaerobic, but specific redox condition could not be determined; Fe, iron reducing; M, methanogenic; Mn, manganese reducing; S, sulfate reducing. Abbreviations: $\mathrm{nM}$, nanomolar; $\mathrm{mg} / \mathrm{L}$, milligram per liter; $\mu \mathrm{S} / \mathrm{cm}$, microsiemens per centimeter at 25 degrees Celsius; ORP, oxidation-reduction potential; mV, millivolt. Symbols: R, data rejected (selected 1996 dissolved-oxygen data were rejected because of inadequate well purging; selected 2002 dissolved-hydrogen data were rejected because of interference from downhole instruments); <, actual value is less than value shown; >, actual value is greater than value shown; -, not analyzed]

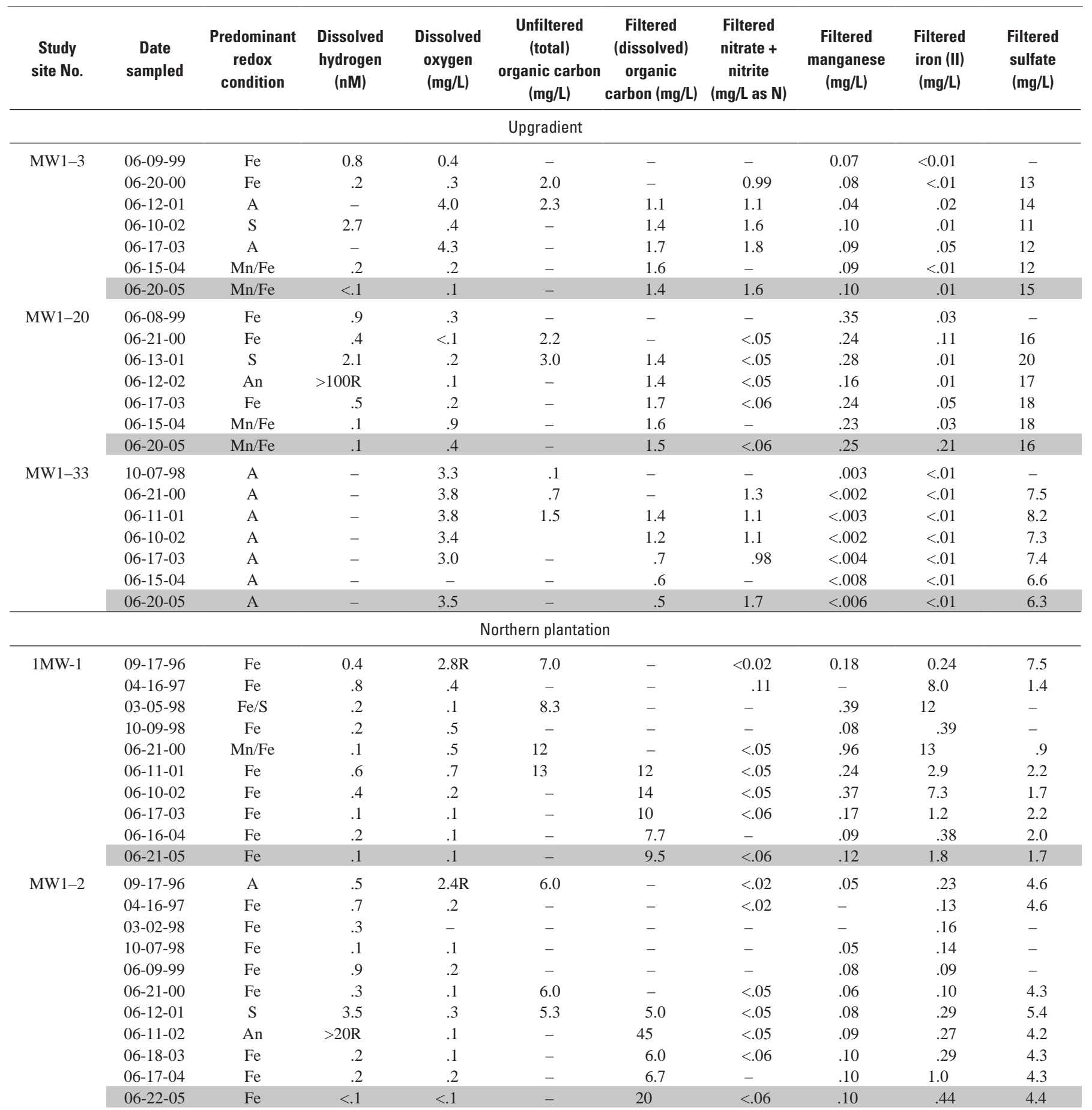


Table 2. Predominant redox conditions at wells and piezometers, and ground-water geochemical data collected at Operable Unit 1, Naval Undersea Warfare Center, Division Keyport, Washington, 1996 to 2005-Continued

[Shaded rows indicate newly published data. All other data were published in Dinicola and others (2002), Dinicola (2003), and Dinicola (2004); prior to 2000, bicarbonate was calculated from an unfiltered sample. Reported concentrations less than the detection limit usually are estimated. A range of dissolved hydrogen concentrations are shown when equilibration at a single value was never achieved. Predominant redox conditions: A, aerobic; An, anaerobic, but specific redox condition could not be determined; Fe, iron reducing; M, methanogenic; Mn, manganese reducing; S, sulfate reducing. Abbreviations: nM, nanomolar; $\mathrm{mg} / \mathrm{L}$, milligram per liter; $\mu \mathrm{S} / \mathrm{cm}$, microsiemens per centimeter at 25 degrees Celsius; ORP, oxidation-reduction potential; mV, millivolt. Symbols: R, data rejected (selected 1996 dissolved-oxygen data were rejected because of inadequate well purging; selected 2002 dissolved-hydrogen data were rejected because of interference from downhole instruments); <, actual value is less than value shown; >, actual value is greater than value shown; -, not analyzed]

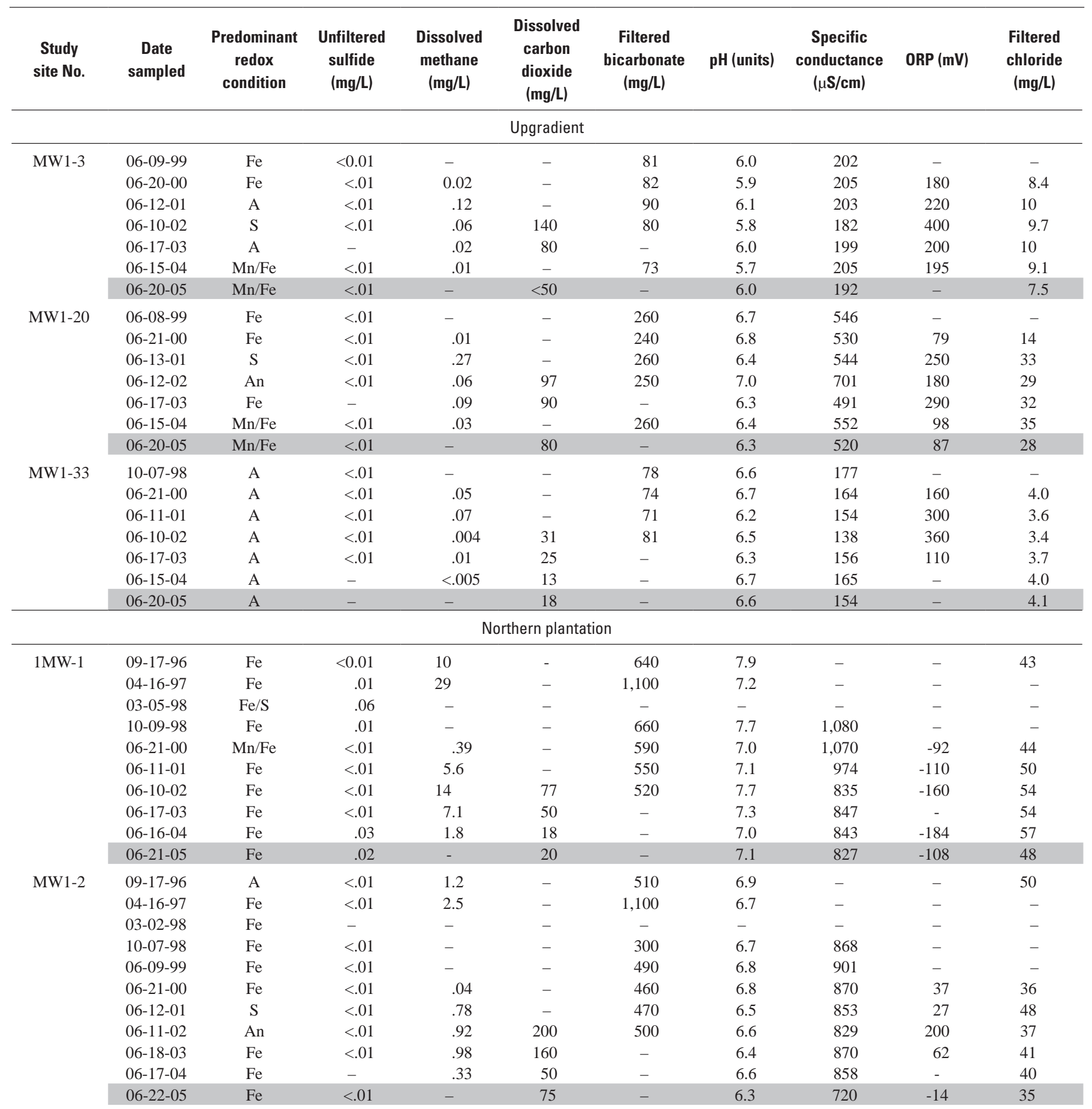


Table 2. Predominant redox conditions at wells and piezometers, and ground-water geochemical data collected at Operable Unit 1, Naval Undersea Warfare Center, Division Keyport, Washington, 1996 to 2005.-Continued

[Shaded rows indicate newly published data. All other data were published in Dinicola and others (2002), Dinicola (2003), and Dinicola (2004); prior to 2000, bicarbonate was calculated from an unfiltered sample. Reported concentrations less than the detection limit usually are estimated. A range of dissolved hydrogen concentrations are shown when equilibration at a single value was never achieved. Predominant redox conditions: A, aerobic; An, anaerobic, but specific redox condition could not be determined; Fe, iron reducing; M, methanogenic; Mn, manganese reducing; S, sulfate reducing. Abbreviations: nM, nanomolar; $\mathrm{mg} / \mathrm{L}$, milligram per liter; $\mu \mathrm{S} / \mathrm{cm}$, microsiemens per centimeter at 25 degrees Celsius; ORP, oxidation-reduction potential; mV, millivolt. Symbols: R, data rejected (selected 1996 dissolved-oxygen data were rejected because of inadequate well purging; selected 2002 dissolved-hydrogen data were rejected because of interference from downhole instruments); <, actual value is less than value shown; >, actual value is greater than value shown; -, not analyzed]

\begin{tabular}{|c|c|c|c|c|c|c|c|c|c|c|}
\hline $\begin{array}{c}\text { Study } \\
\text { site No. }\end{array}$ & $\begin{array}{c}\text { Date } \\
\text { sampled }\end{array}$ & $\begin{array}{c}\text { Predominant } \\
\text { redox } \\
\text { condition }\end{array}$ & $\begin{array}{c}\text { Dissolved } \\
\text { hydrogen } \\
\text { (nM) }\end{array}$ & $\begin{array}{c}\text { Dissolved } \\
\text { oxygen } \\
\text { (mg/L) }\end{array}$ & $\begin{array}{c}\text { Unfiltered } \\
\text { (total) } \\
\text { organic carbon } \\
\text { (mg/L) }\end{array}$ & $\begin{array}{c}\text { Filtered } \\
\text { (dissolved) } \\
\text { organic } \\
\text { carbon (mg/L) }\end{array}$ & $\begin{array}{c}\text { Filtered } \\
\text { nitrate + } \\
\text { nitrite } \\
\text { (mg/L as N) }\end{array}$ & $\begin{array}{c}\text { Filtered } \\
\text { manganese } \\
(\mathrm{mg} / \mathrm{L})\end{array}$ & $\begin{array}{c}\text { Filtered } \\
\text { iron (II) } \\
\text { (mg/L) }\end{array}$ & $\begin{array}{l}\text { Filtered } \\
\text { sulfate } \\
\text { (mg/L) }\end{array}$ \\
\hline \multicolumn{11}{|c|}{ Northern plantation-Continued } \\
\hline \multirow[t]{3}{*}{ MW1-15 } & $09-16-96$ & $\mathrm{Fe}$ & 0.2 & $<0.1$ & 50 & - & $<0.02$ & 5.7 & 68 & 0.1 \\
\hline & $04-16-97$ & $\mathrm{Fe} / \mathrm{S}$ & .8 & $<.1$ & - & - & $<.02$ & - & 77 & .1 \\
\hline & 06-15-04 & $\mathrm{S}$ & 3.2 & .8 & - & 27 & - & 6.3 & 36 & $<.2$ \\
\hline \multirow[t]{4}{*}{ MW1-17 } & 09-17-96 & $\mathrm{Fe}$ & .7 & $<.1$ & 23 & - & $<.02$ & 1.3 & 62 & 4.3 \\
\hline & 04-16-97 & $\mathrm{Fe}$ & .6 & $<.1$ & - & - & $<.02$ & - & 37 & 68 \\
\hline & $10-09-98$ & $\mathrm{Fe}$ & - & $<.1$ & - & - & - & .80 & 56 & - \\
\hline & $06-22-00$ & $\mathrm{~S}$ & 1.2 & $<.1$ & 11 & - & - & 1.2 & 68 & - \\
\hline \multirow{3}{*}{ MW1-18 } & 04-16-97 & $\mathrm{Fe}$ & .5 & $<.1$ & - & - & .05 & - & 23 & 8.2 \\
\hline & $10-07-98$ & $\mathrm{Fe}$ & - & .2 & - & - & - & .77 & 3.3 & - \\
\hline & 06-16-04 & $\mathrm{Fe}$ & .7 & .2 & - & 23 & - & 4.1 & $>10$ & .2 \\
\hline \multirow[t]{7}{*}{ MW1-41 } & 06-09-99 & $\mathrm{S}$ & 1.0 & .3 & - & - & - & 2.2 & 60 & - \\
\hline & $06-21-00$ & $\mathrm{~S}$ & 1.2 & .1 & 22 & - & $<.05$ & 3.5 & 55 & $<.3$ \\
\hline & 06-11-01 & $S$ & 2.0 & .3 & 14 & 14 & $<.05$ & 3.7 & 66 & 30 \\
\hline & $06-10-02$ & $\mathrm{~S}$ & 2.2 & .8 & - & 20 & $<.05$ & 3.6 & 52 & .4 \\
\hline & $06-18-03$ & $\mathrm{~S}$ & 1.9 & $<.1$ & - & 19 & $<.06$ & 3.9 & 50 & $<.2$ \\
\hline & $06-17-04$ & $\mathrm{~S}$ & 2.2 & .1 & - & 19 & - & 4.0 & 57 & $<.2$ \\
\hline & $06-20-05$ & $\mathrm{Fe} / \mathrm{S}$ & .8 & .1 & - & 17 & $<.06$ & 3.9 & 73 & $<2$ \\
\hline \multirow[t]{2}{*}{ P1-1 } & 06-09-99 & $\mathrm{Fe}$ & .7 & .4 & - & - & - & 4.0 & 59 & - \\
\hline & 06-11-02 & $\mathrm{S}$ & 1.4 & $<.1$ & - & 17 & $<.05$ & 2.7 & 40 & $<.1$ \\
\hline $\mathrm{P} 1-3$ & $06-22-05$ & $\mathrm{Fe}$ & .2 & $<.1$ & - & 20 & $<.06$ & 2.8 & 60 & .38 \\
\hline \multirow[t]{6}{*}{$\mathrm{P} 1-4$} & 06-09-99 & $\mathrm{Fe}$ & .7 & .3 & - & - & - & .34 & 2.6 & - \\
\hline & 06-13-01 & $\mathrm{Fe}$ & .1 & .5 & 9.8 & 8.7 & $<.05$ & .38 & 3.4 & 3.8 \\
\hline & 06-11-02 & $\mathrm{Fe}$ & .2 & .1 & - & 8.0 & $<.05$ & 2.6 & 3.7 & 3.5 \\
\hline & 06-18-03 & $\mathrm{Fe}$ & .2 & .1 & - & 7.0 & $<.06$ & .43 & 4.1 & 4.0 \\
\hline & 06-17-04 & $\mathrm{Fe}$ & .1 & .1 & - & 7.6 & - & .42 & 3.0 & 4.0 \\
\hline & $06-21-05$ & $\mathrm{Fe}$ & .1 & .1 & - & 6.7 & $<.06$ & .38 & 2.3 & 4.6 \\
\hline \multirow[t]{5}{*}{ P1-5 } & 06-08-99 & $\mathrm{S}$ & 3.0 & .3 & - & - & - & 3.1 & 72 & - \\
\hline & $06-10-02$ & $\mathrm{~S}$ & 1.7 & .1 & - & 25 & $<.05$ & 2.6 & 62 & $<.6$ \\
\hline & $06-18-03$ & $\mathrm{~S}$ & 2.2 & .1 & - & 24 & $<.06$ & 3.1 & 54 & $<.2$ \\
\hline & 06-17-04 & $\mathrm{S}$ & 2.1 & $<.1$ & - & 23 & - & 3.1 & $>10$ & $<.2$ \\
\hline & $06-21-05$ & $\mathrm{Fe} / \mathrm{S}$ & .8 & .1 & - & 22 & $<.06$ & 3.5 & 74 & E. 1 \\
\hline
\end{tabular}


Table 2. Predominant redox conditions at wells and piezometers, and ground-water geochemical data collected at Operable Unit 1, Naval Undersea Warfare Center, Division Keyport, Washington, 1996 to 2005-Continued

[Shaded rows indicate newly published data. All other data were published in Dinicola and others (2002), Dinicola (2003), and Dinicola (2004); prior to 2000, bicarbonate was calculated from an unfiltered sample. Reported concentrations less than the detection limit usually are estimated. A range of dissolved hydrogen concentrations are shown when equilibration at a single value was never achieved. Predominant redox conditions: A, aerobic; An, anaerobic, but specific redox condition could not be determined; Fe, iron reducing; M, methanogenic; Mn, manganese reducing; S, sulfate reducing. Abbreviations: nM, nanomolar; $\mathrm{mg} / \mathrm{L}$, milligram per liter; $\mu \mathrm{S} / \mathrm{cm}$, microsiemens per centimeter at 25 degrees Celsius; ORP, oxidation-reduction potential; mV, millivolt. Symbols: R, data rejected (selected 1996 dissolved-oxygen data were rejected because of inadequate well purging; selected 2002 dissolved-hydrogen data were rejected because of interference from downhole instruments); <, actual value is less than value shown; >, actual value is greater than value shown; -, not analyzed]

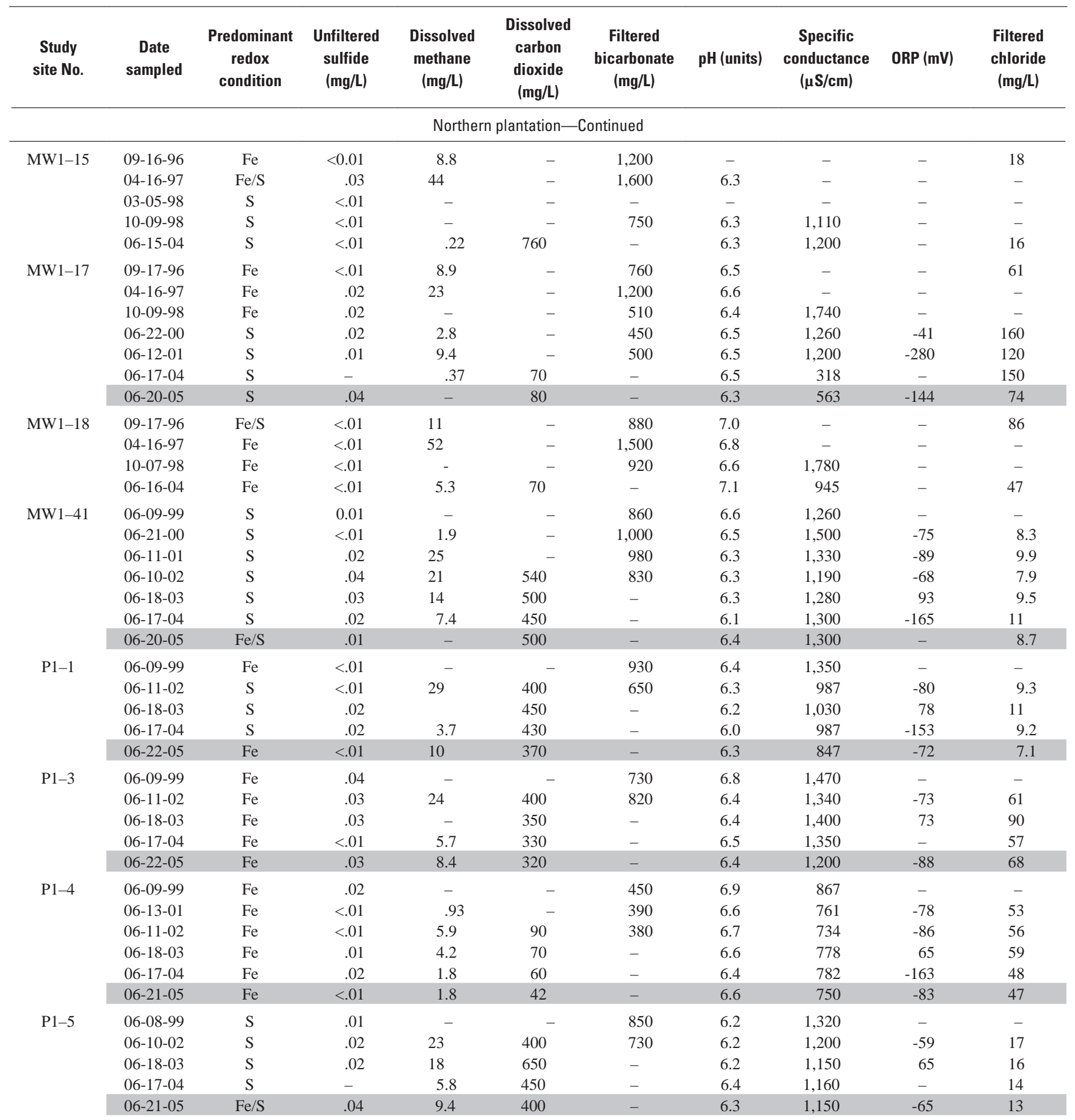


Table 2. Predominant redox conditions at wells and piezometers, and ground-water geochemical data collected at Operable Unit 1, Naval Undersea Warfare Center, Division Keyport, Washington, 1996 to 2005.-Continued

[Shaded rows indicate newly published data. All other data were published in Dinicola and others (2002), Dinicola (2003), and Dinicola (2004); prior to 2000, bicarbonate was calculated from an unfiltered sample. Reported concentrations less than the detection limit usually are estimated. A range of dissolved hydrogen concentrations are shown when equilibration at a single value was never achieved. Predominant redox conditions: A, aerobic; An, anaerobic, but specific redox condition could not be determined; Fe, iron reducing; M, methanogenic; Mn, manganese reducing; S, sulfate reducing. Abbreviations: $\mathrm{nM}$, nanomolar; $\mathrm{mg} / \mathrm{L}$, milligram per liter; $\mu \mathrm{S} / \mathrm{cm}$, microsiemens per centimeter at 25 degrees Celsius; ORP, oxidation-reduction potential; mV, millivolt. Symbols: R, data rejected (selected 1996 dissolved-oxygen data were rejected because of inadequate well purging; selected 2002 dissolved-hydrogen data were rejected because of interference from downhole instruments); <, actual value is less than value shown; >, actual value is greater than value shown; -, not analyzed]

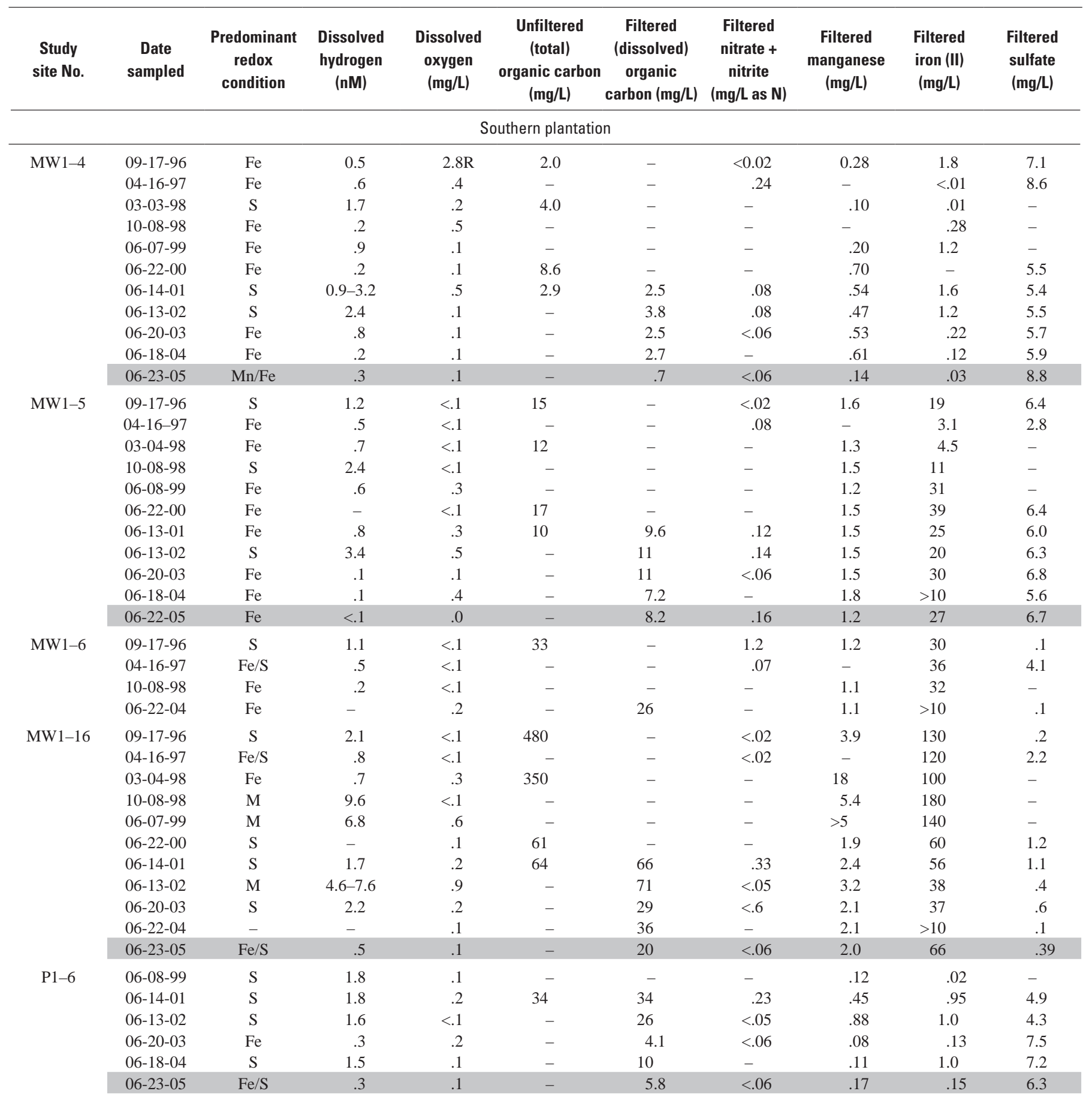


Table 2. Predominant redox conditions at wells and piezometers, and ground-water geochemical data collected at Operable Unit 1, Naval Undersea Warfare Center, Division Keyport, Washington, 1996 to 2005.-Continued

[Shaded rows indicate newly published data. All other data were published in Dinicola and others (2002), Dinicola (2003), and Dinicola (2004); prior to 2000, bicarbonate was calculated from an unfiltered sample. Reported concentrations less than the detection limit usually are estimated. A range of dissolved hydrogen concentrations are shown when equilibration at a single value was never achieved. Predominant redox conditions: A, aerobic; An, anaerobic, but specific redox condition could not be determined; Fe, iron reducing; M, methanogenic; Mn, manganese reducing; S, sulfate reducing. Abbreviations: nM, nanomolar; $\mathrm{mg} / \mathrm{L}$, milligram per liter; $\mu \mathrm{S} / \mathrm{cm}$, microsiemens per centimeter at 25 degrees Celsius; ORP, oxidation-reduction potential; mV, millivolt. Symbols: R, data rejected (selected 1996 dissolved-oxygen data were rejected because of inadequate well purging; selected 2002 dissolved-hydrogen data were rejected because of interference from downhole instruments); <, actual value is less than value shown; >, actual value is greater than value shown; -, not analyzed]

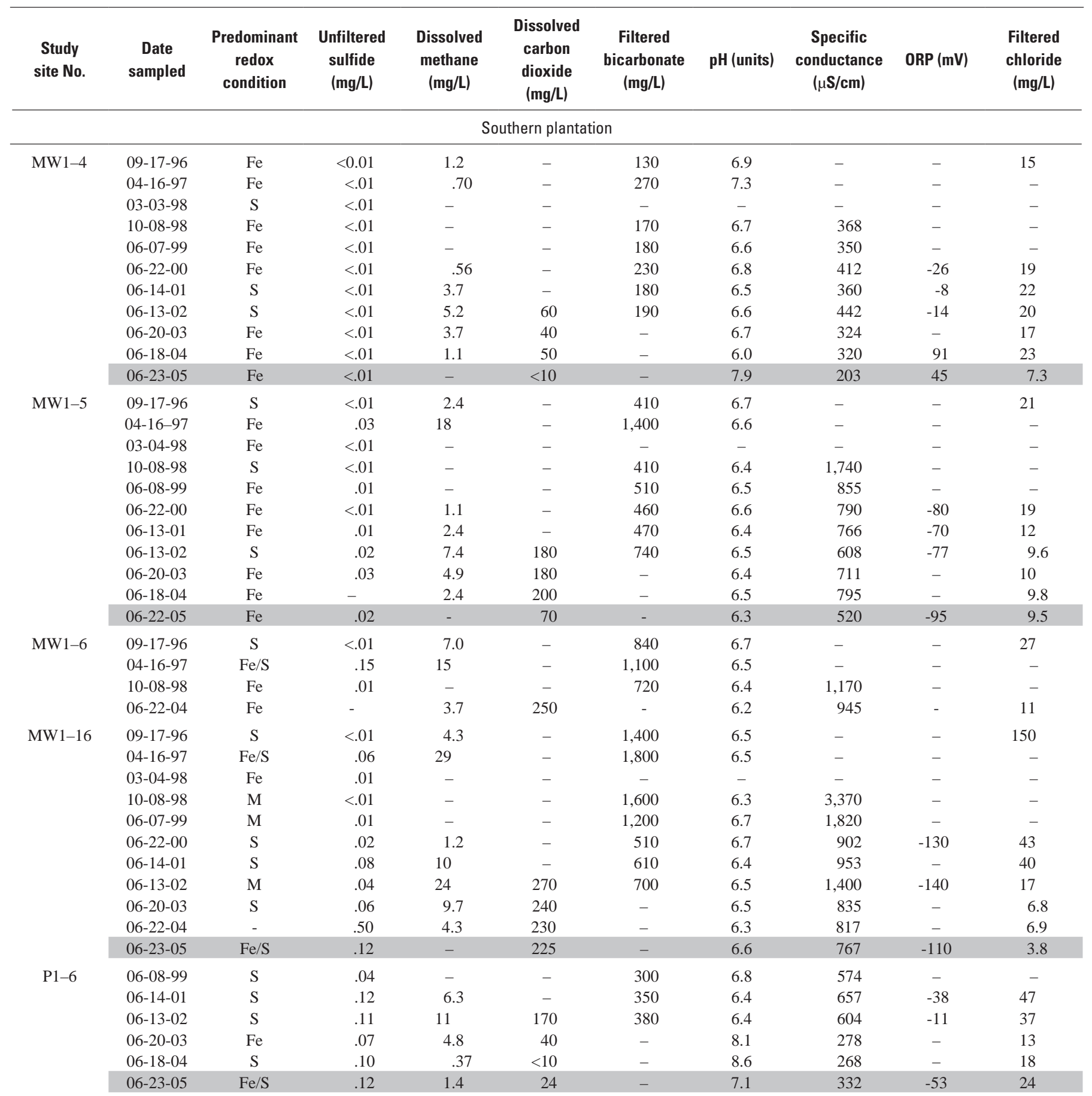


Table 2. Predominant redox conditions at wells and piezometers, and ground-water geochemical data collected at Operable Unit 1, Naval Undersea Warfare Center, Division Keyport, Washington, 1996 to 2005.-Continued

[Shaded rows indicate newly published data. All other data were published in Dinicola and others (2002), Dinicola (2003), and Dinicola (2004); prior to 2000, bicarbonate was calculated from an unfiltered sample. Reported concentrations less than the detection limit usually are estimated. A range of dissolved hydrogen concentrations are shown when equilibration at a single value was never achieved. Predominant redox conditions: A, aerobic; An, anaerobic, but specific redox condition could not be determined; Fe, iron reducing; M, methanogenic; Mn, manganese reducing; S, sulfate reducing. Abbreviations: $\mathrm{nM}$, nanomolar; $\mathrm{mg} / \mathrm{L}$, milligram per liter; $\mu \mathrm{S} / \mathrm{cm}$, microsiemens per centimeter at 25 degrees Celsius; ORP, oxidation-reduction potential; mV, millivolt. Symbols: R, data rejected (selected 1996 dissolved-oxygen data were rejected because of inadequate well purging; selected 2002 dissolved-hydrogen data were rejected because of interference from downhole instruments); <, actual value is less than value shown; >, actual value is greater than value shown; -, not analyzed]

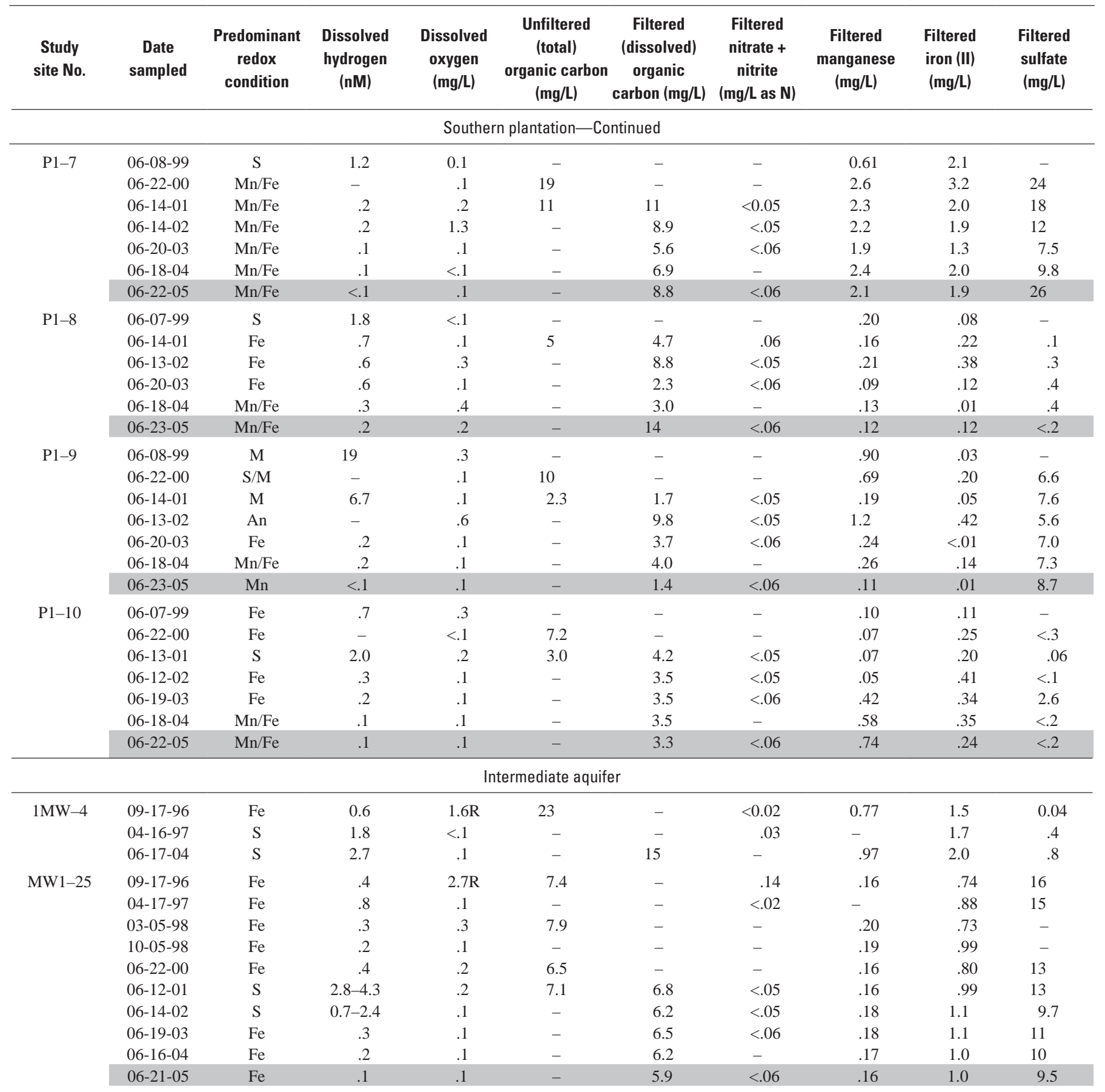


Table 2. Predominant redox conditions at wells and piezometers, and ground-water geochemical data collected at Operable Unit 1, Naval Undersea Warfare Center, Division Keyport, Washington, 1996 to 2005.-Continued

[Shaded rows indicate newly published data. All other data were published in Dinicola and others (2002), Dinicola (2003), and Dinicola (2004); prior to 2000, bicarbonate was calculated from an unfiltered sample. Reported concentrations less than the detection limit usually are estimated. A range of dissolved hydrogen concentrations are shown when equilibration at a single value was never achieved. Predominant redox conditions: A, aerobic; An, anaerobic, but specific redox condition could not be determined; Fe, iron reducing; M, methanogenic; Mn, manganese reducing; S, sulfate reducing. Abbreviations: nM, nanomolar; $\mathrm{mg} / \mathrm{L}$, milligram per liter; $\mu \mathrm{S} / \mathrm{cm}$, microsiemens per centimeter at 25 degrees Celsius; ORP, oxidation-reduction potential; mV, millivolt. Symbols: R, data rejected (selected 1996 dissolved-oxygen data were rejected because of inadequate well purging; selected 2002 dissolved-hydrogen data were rejected because of interference from downhole instruments); <, actual value is less than value shown; >, actual value is greater than value shown; -, not analyzed]

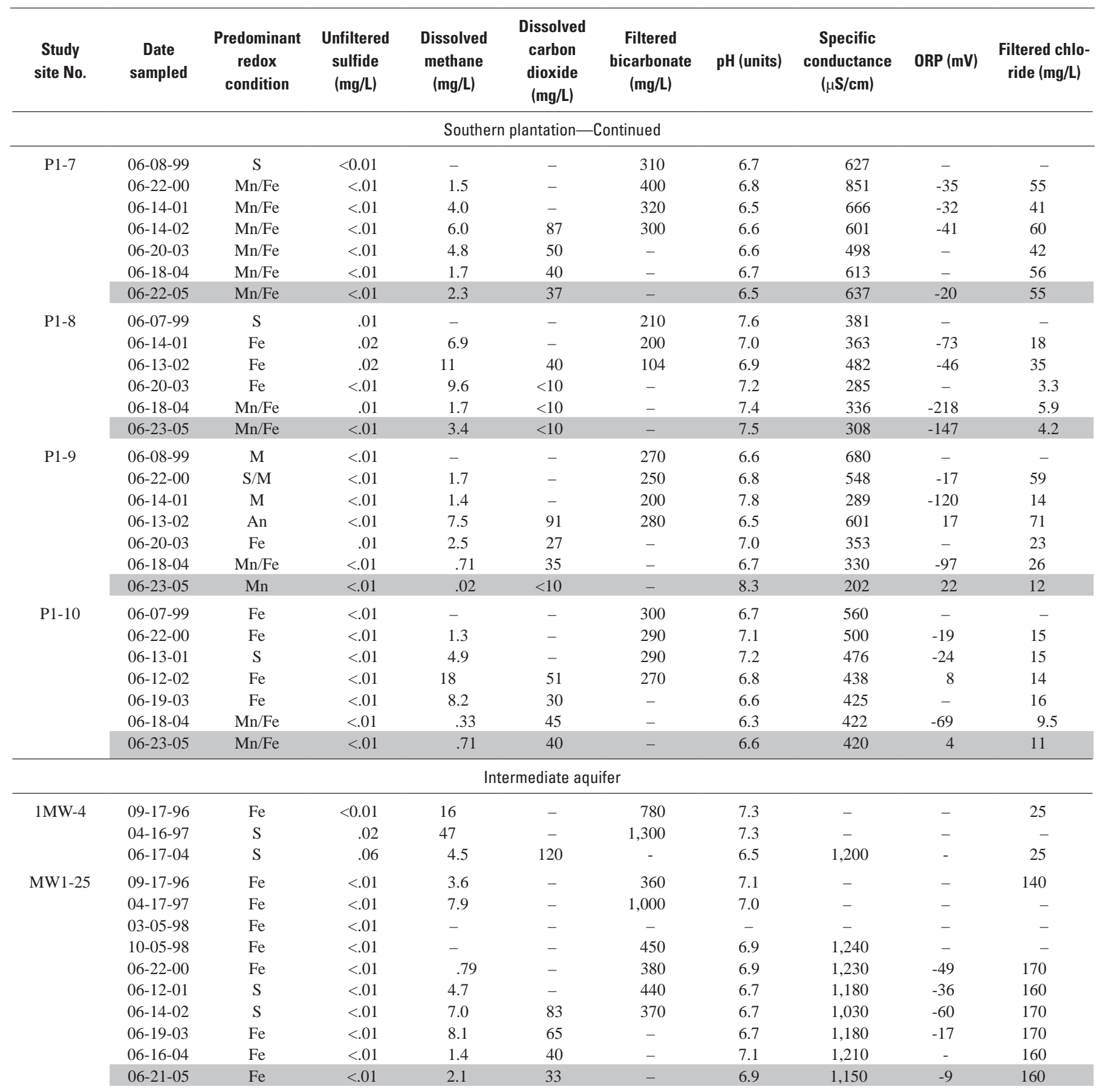


Table 2. Predominant redox conditions at wells and piezometers, and ground-water geochemical data collected at Operable Unit 1, Naval Undersea Warfare Center, Division Keyport, Washington, 1996 to 2005.-Continued

[Shaded rows indicate newly published data. All other data were published in Dinicola and others (2002), Dinicola (2003), and Dinicola (2004); prior to 2000, bicarbonate was calculated from an unfiltered sample. Reported concentrations less than the detection limit usually are estimated. A range of dissolved hydrogen concentrations are shown when equilibration at a single value was never achieved. Predominant redox conditions: A, aerobic; An, anaerobic, but specific redox condition could not be determined; Fe, iron reducing; M, methanogenic; Mn, manganese reducing; S, sulfate reducing. Abbreviations: $\mathrm{nM}$, nanomolar; $\mathrm{mg} / \mathrm{L}$, milligram per liter; $\mu \mathrm{S} / \mathrm{cm}$, microsiemens per centimeter at 25 degrees Celsius; ORP, oxidation-reduction potential; mV, millivolt. Symbols: R, data rejected (selected 1996 dissolved-oxygen data were rejected because of inadequate well purging; selected 2002 dissolved-hydrogen data were rejected because of interference from downhole instruments); <, actual value is less than value shown; >, actual value is greater than value shown; -, not analyzed]

\begin{tabular}{|c|c|c|c|c|c|c|c|c|c|c|}
\hline $\begin{array}{c}\text { Study } \\
\text { site No. }\end{array}$ & $\begin{array}{c}\text { Date } \\
\text { sampled }\end{array}$ & $\begin{array}{c}\text { Predominant } \\
\text { redox } \\
\text { condition }\end{array}$ & $\begin{array}{l}\text { Dissolved } \\
\text { hydrogen } \\
\text { (nM) }\end{array}$ & $\begin{array}{c}\text { Dissolved } \\
\text { oxygen } \\
\text { (mg/L) }\end{array}$ & $\begin{array}{c}\text { Unfiltered } \\
\text { (total) } \\
\text { organic carbon } \\
\text { (mg/L) }\end{array}$ & 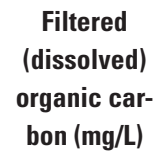 & $\begin{array}{c}\text { Filtered ni- } \\
\text { trate + nitrite } \\
\text { (mg/L as N) }\end{array}$ & $\begin{array}{c}\text { Filtered } \\
\text { manganese } \\
(\mathrm{mg} / \mathrm{L})\end{array}$ & $\begin{array}{c}\text { Filtered } \\
\text { iron (II) } \\
(\mathrm{mg} / \mathrm{L})\end{array}$ & $\begin{array}{l}\text { Filtered } \\
\text { sulfate } \\
(\mathrm{mg} / \mathrm{L})\end{array}$ \\
\hline \multicolumn{11}{|c|}{ Intermediate aquifer-Continued } \\
\hline \multirow[t]{8}{*}{ MW1-28 } & $09-16-96$ & $\mathrm{Fe}$ & 0.3 & $2.1 \mathrm{R}$ & 7.2 & - & $<0.02$ & 0.20 & 1.0 & 48 \\
\hline & $04-17-97$ & $\mathrm{Fe}$ & 1.0 & $<.1$ & - & - & .04 & - & .99 & 51 \\
\hline & $06-22-00$ & $\mathrm{Fe}$ & .3 & $<.1$ & 13 & - & - & .16 & .66 & 44 \\
\hline & $06-12-01$ & $\mathrm{~S} / \mathrm{M}$ & $4.1-5.7$ & .5 & 10 & 6.9 & $<.05$ & .16 & .90 & 45 \\
\hline & 06-14-02 & An & $>100 \mathrm{R}$ & .1 & - & 7.0 & $<.05$ & .16 & .92 & 39 \\
\hline & 06-19-03 & S & 2.5 & .1 & - & 6.8 & $<.06$ & .16 & .66 & 39 \\
\hline & $06-16-04$ & $\mathrm{Mn} / \mathrm{Fe}$ & .2 & .1 & - & 5.9 & - & .18 & $<.01$ & 36 \\
\hline & $06-21-05$ & $\mathrm{Fe}$ & .1 & .2 & - & 6.3 & $<.06$ & .16 & .98 & 37 \\
\hline \multirow[t]{5}{*}{ MW1-38 } & $10-09-98$ & $\mathrm{Fe}$ & - & .1 & - & - & - & .20 & .08 & - \\
\hline & $06-20-00$ & $\mathrm{Fe}$ & .1 & .2 & 5.6 & - & $<.05$ & .08 & .10 & 2.3 \\
\hline & $06-12-02$ & S & 1.4 & $<.1$ & 5.0 & - & $<.05$ & .08 & .42 & 2.9 \\
\hline & 06-16-04 & $\mathrm{Mn} / \mathrm{Fe}$ & .2 & .1 & - & 4.9 & - & .06 & .04 & 1.2 \\
\hline & 06-24-05 & $\mathrm{Fe}$ & .3 & .1 & - & 4.4 & $<.06$ & .06 & .09 & 3.3 \\
\hline \multirow[t]{7}{*}{ MW1-39 } & $09-16-96$ & $\mathrm{Fe} / \mathrm{S}$ & .6 & $2.0 \mathrm{R}$ & 4.4 & - & $<.02$ & .02 & $<.01$ & .7 \\
\hline & 04-17-97 & $\mathrm{S}$ & 4.5 & $<.1$ & - & - & $<.02$ & - & .05 & 13 \\
\hline & 03-03-98 & $\mathrm{Fe} / \mathrm{S}$ & .3 & .3 & 3.7 & - & - & .10 & .03 & - \\
\hline & $10-09-98$ & $\mathrm{Fe} / \mathrm{S}$ & .5 & $<.1$ & - & - & - & $<.01$ & .04 & - \\
\hline & 06-07-99 & $\mathrm{Fe} / \mathrm{S}$ & 1.0 & .3 & - & - & - & .10 & .02 & - \\
\hline & $06-20-00$ & $\mathrm{Fe} / \mathrm{S}$ & .5 & .1 & 2.4 & - & $<.05$ & .01 & .07 & .2 \\
\hline & $06-12-01$ & S & 1.4 & .3 & 3.4 & 3.3 & $<.05$ & .01 & $<.01$ & .1 \\
\hline
\end{tabular}


Table 2. Predominant redox conditions at wells and piezometers, and ground-water geochemical data collected at Operable Unit 1, Naval Undersea Warfare Center, Division Keyport, Washington, 1996 to 2005.-Continued

[Shaded rows indicate newly published data All other data were published in Dinicola and others (2002), Dinicola (2003), and Dinicola (2004); prior to 2000, bicarbonate was calculated from an unfiltered sample. Reported concentrations less than the detection limit usually are estimated. A range of dissolved hydrogen concentrations are shown when equilibration at a single value was never achieved. Predominant redox conditions: A, aerobic; An, anaerobic, but specific redox condition could not be determined; Fe, iron reducing; M, methanogenic; Mn, manganese reducing; S, sulfate reducing. Abbreviations: nM, nanomolar; $\mathrm{mg} / \mathrm{L}$, milligrams per liter; $\mu \mathrm{S} / \mathrm{cm}$, microsiemens per centimeter at 25 degrees Celsius; ORP, oxidation-reduction potential; mV, millivolt. Symbols: R, data rejected (selected 1996 dissolved-oxygen data were rejected because of inadequate well purging; selected 2002 dissolved-hydrogen data were rejected because of interference from downhole instruments); <, actual value is less than value shown; >, actual value is greater than value shown; -, not analyzed]

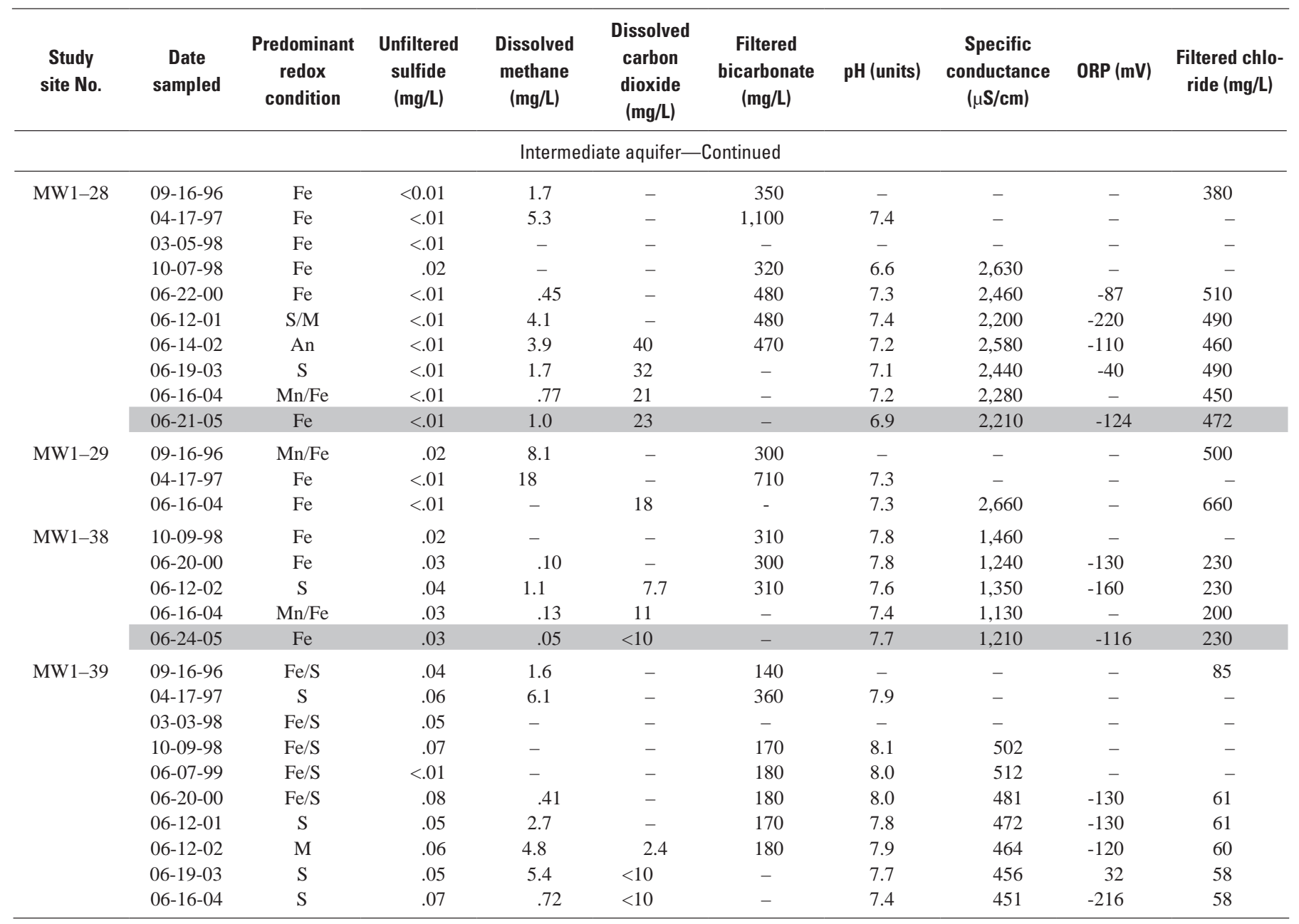


Table 3. Concentrations of selected volatile organic compounds in ground-water samples from monitoring wells, piezometers, and diffusion samplers, and in surface-water samples from the marsh stream collected by the USGS from 1999 to 2005 at Operable Unit 1, Naval Undersea Warfare Center, Division Keyport, Washington.

[All data except those shaded were published previously in Dinicola and others (2002), Dinicola (2003), Dinicola (2004), and Dinicola and Huffman (2004). Reported concentrations less than the detection limit are estimated. Laboratory data qualifier codes, such as "D" for dilution, are not shown. Volatile organic compounds (VOCs): PCE, tetrachloroethene; TCE, trichloroethene; cis-DCE, cis-1,2-dichloroethene; trans-DCE, trans-1,2-dichloroethene; VC, vinyl chloride; 1,1,1-TCA, 1,1,1-trichloroethane; 1,1-DCA, 1,1-dichloroethane; CA, chloroethane; 1,1-DCE, 1,1-dichloroethene; total BTEX, sum of benzene, toluene, ethylbenzene, and xylene; total CVOCs, sum of chlorinated volatile organic compounds. Methane data are presented for diffusion samplers only. Abbreviations: E, estimated value; $\mu \mathrm{g} / \mathrm{L}$, microgram per liter; dup, duplicate; blank, field blank; <, actual value is less than value shown; nd, not detected; -, not analyzed]

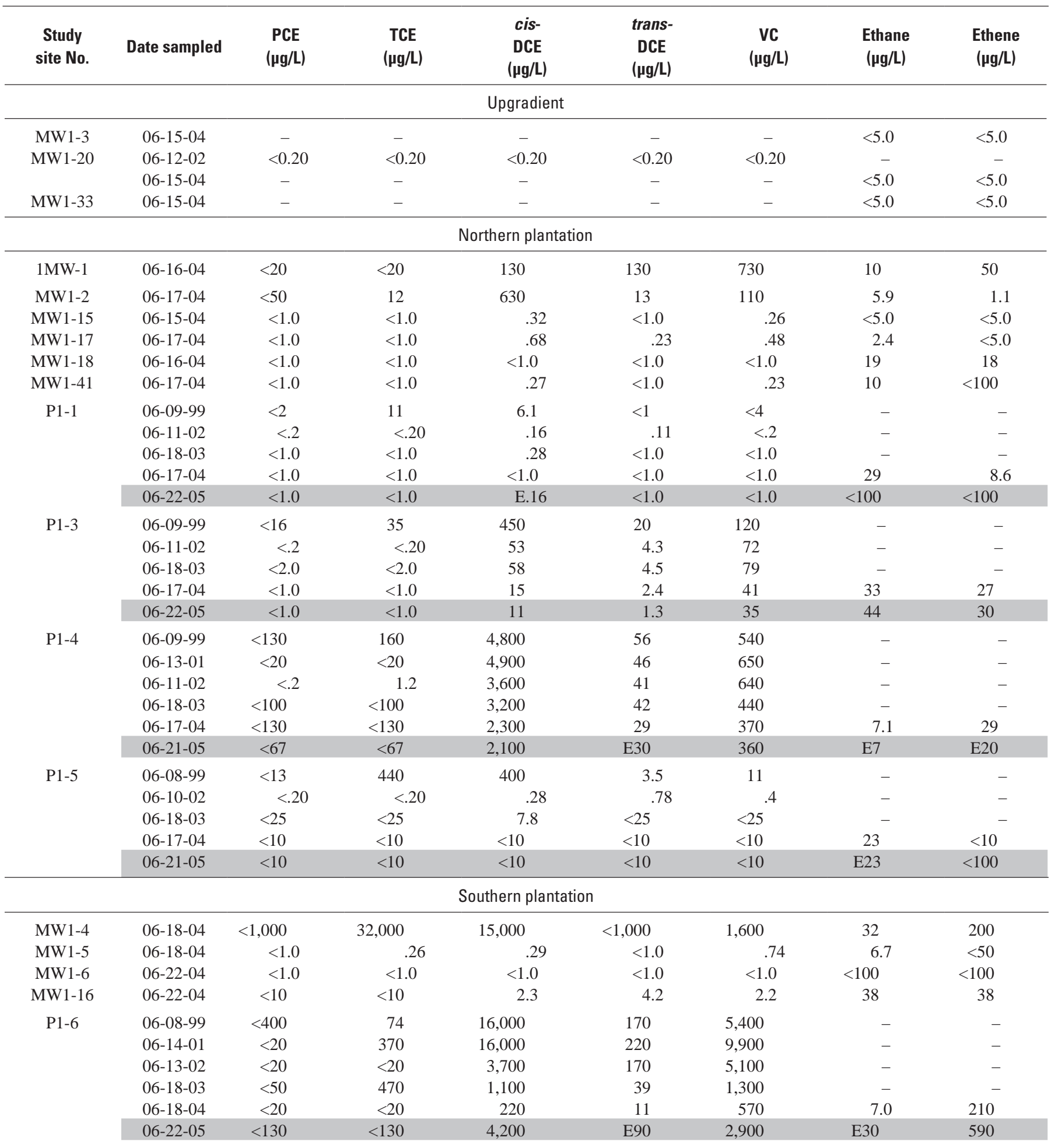


Table 3. Concentrations of selected volatile organic compounds in ground-water samples from monitoring wells, piezometers, and diffusion samplers, and in surface-water samples from the marsh stream collected by the USGS from 1999 to 2005 at Operable Unit 1, Naval Undersea Warfare Center, Division Keyport, Washington.-Continued.

[All data except those shaded were published previously in Dinicola and others (2002), Dinicola (2003), Dinicola (2004), and Dinicola and Huffman (2004). Reported concentrations less than the detection limit are estimated. Laboratory data qualifier codes, such as " $\mathrm{D}$ " for dilution, are not shown. Volatile organic compounds (VOCs): PCE, tetrachloroethene; TCE, trichloroethene; cis-DCE, cis-1,2-dichloroethene; trans-DCE, trans-1,2-dichloroethene; VC, vinyl chloride; 1,1,1-TCA, 1,1,1-trichloroethane; 1,1-DCA, 1,1-dichloroethane; CA, chloroethane; 1,1-DCE, 1,1-dichloroethene; total BTEX, sum of benzene, toluene, ethylbenzene, and xylene; total CVOCs, sum of chlorinated volatile organic compounds. Methane data are presented for diffusion samplers only. Abbreviations: E, estimated value; $\mu \mathrm{g} / \mathrm{L}$, microgram per liter; dup, duplicate; blank, field blank; <, actual value is less than value shown; nd, not detected; -, not analyzed]

\begin{tabular}{|c|c|c|c|c|c|c|c|}
\hline $\begin{array}{c}\text { Study } \\
\text { site No. }\end{array}$ & Date sampled & $\begin{array}{c}\text { 1,1,1-TCA } \\
(\mu \mathrm{g} / \mathrm{L})\end{array}$ & $\begin{array}{c}\text { 1,1-DCA } \\
(\mu \mathrm{g} / \mathrm{L})\end{array}$ & $\begin{array}{c}\text { CA } \\
(\mu \mathrm{g} / \mathrm{L})\end{array}$ & $\begin{array}{c}\text { 1,1-DCE } \\
(\mu \mathrm{g} / \mathrm{L})\end{array}$ & $\begin{array}{l}\text { Total } \\
\text { BTEX } \\
\text { ( } \mu \mathrm{g} / \mathrm{L})\end{array}$ & $\begin{array}{c}\text { Total } \\
\text { CVOCs } \\
\text { ( } \mu \mathrm{g} / \mathrm{L} \text { ) }\end{array}$ \\
\hline \multicolumn{8}{|c|}{ Upgradient } \\
\hline MW1-3 & $06-15-04$ & - & - & - & - & - & - \\
\hline \multirow[t]{2}{*}{ MW1-20 } & $06-12-02$ & $<0.20$ & $<0.20$ & $<0.20$ & $<0.20$ & nd & nd \\
\hline & $06-15-04$ & - & - & - & - & - & - \\
\hline MW1-33 & $06-15-04$ & - & - & - & - & - & - \\
\hline \multicolumn{8}{|c|}{ Northern plantation } \\
\hline 1MW-1 & 06-16-04 & $<20$ & 11 & $<40$ & $<20$ & nd & 1,000 \\
\hline MW1-2 & $06-17-04$ & $<50$ & $<50$ & $<100$ & $<50$ & nd & 770 \\
\hline MW1-15 & $06-15-04$ & $<1.0$ & $<1.0$ & .88 & $<1.0$ & 30 & 1.5 \\
\hline MW1-17 & $06-17-04$ & $<1.0$ & $<1.0$ & $<2.0$ & $<1.0$ & .31 & 1.4 \\
\hline MW1-18 & $06-16-04$ & $<1.0$ & $<1.0$ & $<2.0$ & $<1.0$ & nd & nd \\
\hline MW1-41 & 06-17-04 & $<1.0$ & $<1.0$ & 1.7 & $<1.0$ & nd & 2.2 \\
\hline \multirow[t]{5}{*}{ P1-1 } & 06-09-99 & $<2$ & .24 & $<4$ & $<2$ & 19 & 17 \\
\hline & 06-11-02 & $<.20$ & .46 & $<.2$ & $<.20$ & 6.8 & .73 \\
\hline & $06-18-03$ & $<1.0$ & .26 & $<2.0$ & $<1.0$ & 3.9 & .54 \\
\hline & 06-17-04 & $<1.0$ & $<1.0$ & $<2.0$ & $<1.0$ & 4.4 & nd \\
\hline & $06-22-05$ & $<1.0$ & $<1.0$ & E.19 & $<1.0$ & 3.5 & .35 \\
\hline \multirow[t]{5}{*}{ P1-3 } & 06-09-99 & $<16$ & $<16$ & 3.6 & $<16$ & nd & 630 \\
\hline & 06-11-02 & $<.20$ & .60 & 9.9 & .20 & 3.3 & 140 \\
\hline & $06-18-03$ & $<2.0$ & .56 & 5.2 & $<2.0$ & 1.7 & 150 \\
\hline & $06-17-04$ & $<1.0$ & .38 & 6.9 & $<1.0$ & 2.4 & 66 \\
\hline & $06-22-05$ & $<1.0$ & .31 & 2.6 & $<1.0$ & 2.3 & 65 \\
\hline \multirow[t]{6}{*}{ P1-4 } & 06-09-99 & $<130$ & $<130$ & $<270$ & $<130$ & nd & 5,600 \\
\hline & $06-13-01$ & $<20$ & $<20$ & $<20$ & $<20$ & nd & 5,600 \\
\hline & $06-11-02$ & $<.20$ & $<10$ & .8 & 9.9 & 1.1 & 4,300 \\
\hline & 06-18-03 & $<100$ & $<100$ & $<200$ & $<100$ & nd & 3,700 \\
\hline & $06-17-04$ & $<130$ & $<130$ & $<270$ & $<130$ & nd & 2,700 \\
\hline & $06-21-05$ & $<67$ & $<67$ & $<130$ & $<67$ & nd & 2,500 \\
\hline \multirow[t]{5}{*}{$\mathrm{P} 1-5$} & 06-08-99 & $<13$ & $<13$ & 15 & $<13$ & 47 & 870 \\
\hline & $06-10-02$ & $<.20$ & .27 & 20.9 & $<.20$ & 18 & 23 \\
\hline & $06-18-03$ & $<25$ & $<25$ & 19 & $<25$ & nd & 27 \\
\hline & $06-17-04$ & $<10$ & $<10$ & 23 & $<10$ & 4.5 & 23 \\
\hline & $06-21-05$ & $<10$ & $<10$ & 21 & $<10$ & 8.2 & 33 \\
\hline \multicolumn{8}{|c|}{ Southern plantation } \\
\hline MW1-4 & $06-18-04$ & $<1,000$ & $<1,000$ & $<2,000$ & $<1,000$ & nd & 49,000 \\
\hline MW1-5 & $06-18-04$ & $<1.0$ & .36 & 3 & $<1.0$ & 0.92 & 4.6 \\
\hline MW1-6 & $06-22-04$ & $<1.0$ & $<1.0$ & 1.7 & $<1.0$ & 1.9 & 1.7 \\
\hline MW1-16 & $06-22-04$ & $<10$ & 590 & 290 & $<10$ & 370 & 900 \\
\hline \multirow[t]{6}{*}{ P1-6 } & 06-08-99 & $<400$ & 1,500 & 300 & $<400$ & nd & 23,000 \\
\hline & 06-14-01 & $<20$ & 4,800 & 610 & 11 & 88 & 32,000 \\
\hline & 06-13-02 & $<20$ & 4,300 & 1,400 & $<20$ & 63 & 15,000 \\
\hline & $06-18-03$ & $<50$ & 380 & 270 & $<50$ & nd & 3,600 \\
\hline & $06-18-04$ & $<20$ & 200 & 88 & $<20$ & nd & 1,100 \\
\hline & $06-22-05$ & $<130$ & $<130$ & 400 & $<130$ & nd & 7,600 \\
\hline
\end{tabular}


Table 3. Concentrations of selected volatile organic compounds in ground-water samples from monitoring wells, piezometers, and diffusion samplers, and in surface-water samples from the marsh stream collected by the USGS from 1999 to 2005 at Operable Unit 1, Naval Undersea Warfare Center, Division Keyport, Washington—Continued.

[All data except those shaded were published previously in Dinicola and others (2002), Dinicola (2003), Dinicola (2004), and Dinicola and Huffman (2004). Reported concentrations less than the detection limit are estimated. Laboratory data qualifier codes, such as "D" for dilution, are not shown. Volatile organic compounds (VOCs); PCE, tetrachloroethene; TCE, trichloroethene; cis-DCE, cis-1,2-dichloroethene; trans-DCE, trans-1,2-dichloroethene; VC, vinyl chloride; 1,1,1-TCA, 1,1,1-trichloroethane; 1,1-DCA, 1,1-dichloroethane; CA, chloroethane; 1,1-DCE, 1,1-dichloroethene; total BTEX, sum of benzene, toluene, ethylbenzene, and xylene; total CVOCs, sum of chlorinated volatile organic compounds. Methane data are presented for diffusion samplers only. Abbreviations: E, estimated value; $\mu \mathrm{g} / \mathrm{L}$, microgram per liter; dup, duplicate; blank, field blank; <, actual value is less than value shown; nd, not detected; -, not analyzed]

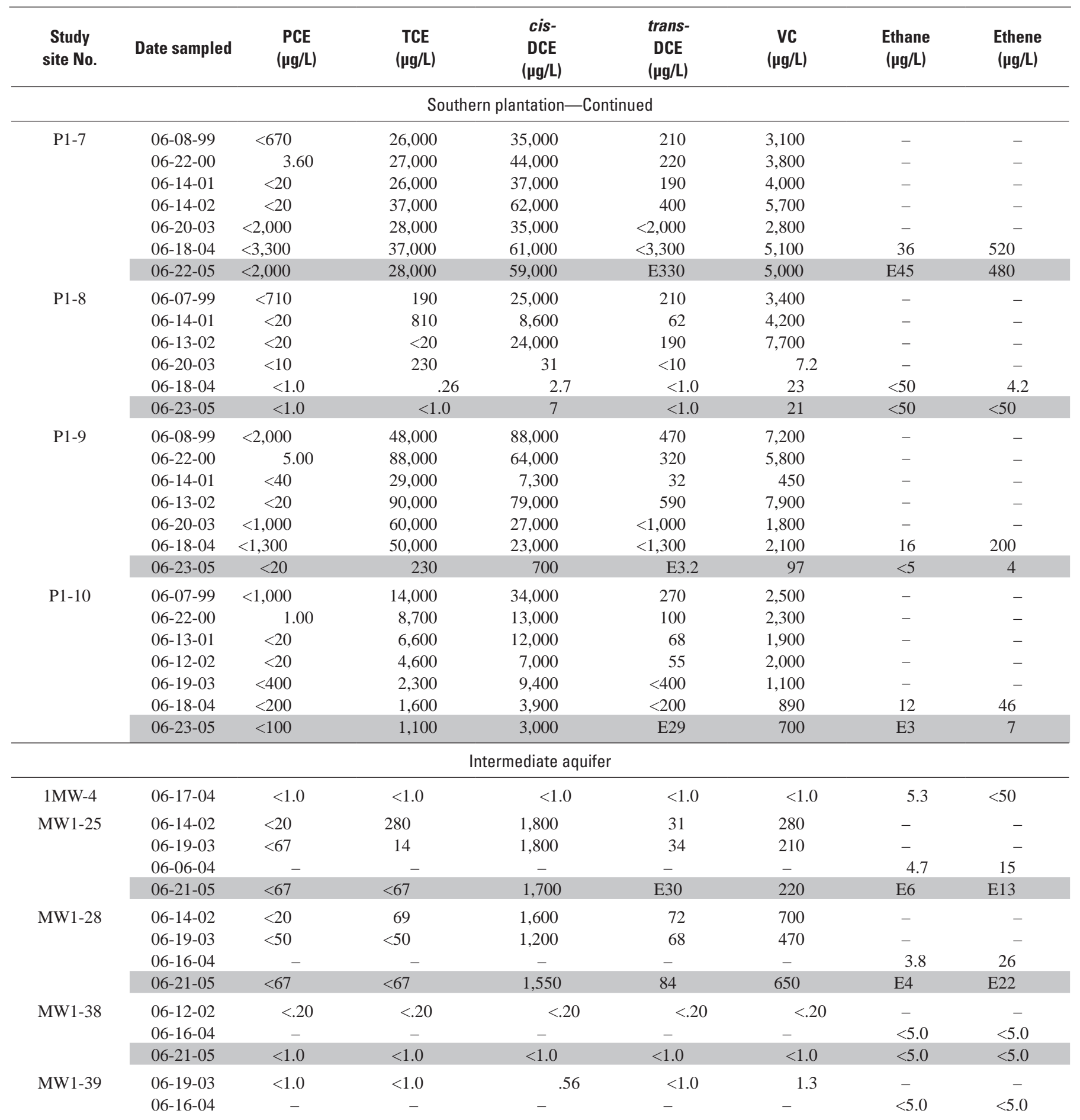


Table 3. Concentrations of selected volatile organic compounds in ground-water samples from monitoring wells, piezometers, and diffusion samplers, and in surface-water samples from the marsh stream collected by the USGS from 1999 to 2005 at Operable Unit 1, Naval Undersea Warfare Center, Division Keyport, Washington—Continued.

[All data except those shaded were published previously in Dinicola and others (2002), Dinicola (2003), Dinicola (2004), and Dinicola and Huffman (2004). Reported concentrations less than the detection limit are estimated. Laboratory data qualifier codes, such as " $\mathrm{D}$ " for dilution, are not shown. Volatile organic compounds (VOCs); PCE, tetrachloroethene; TCE, trichloroethene; cis-DCE, cis-1,2-dichloroethene; trans-DCE, trans-1,2-dichloroethene; VC, vinyl chloride; 1,1,1-TCA, 1,1,1-trichloroethane; 1,1-DCA, 1,1-dichloroethane; CA, chloroethane; 1,1-DCE, 1,1-dichloroethene; total BTEX, sum of benzene, toluene, ethylbenzene, and xylene; total CVOCs, sum of chlorinated volatile organic compounds. Methane data are presented for diffusion samplers only. Abbreviations: E, estimated value; $\mu \mathrm{g} / \mathrm{L}$, microgram per liter; dup, duplicate; blank, field blank; <, actual value is less than value shown; nd, not detected; -, not analyzed]

\begin{tabular}{|c|c|c|c|c|c|c|c|}
\hline $\begin{array}{c}\text { Study } \\
\text { site No. }\end{array}$ & Date sampled & $\begin{array}{c}\text { 1,1,1-TCA } \\
(\mu \mathrm{g} / \mathrm{L})\end{array}$ & $\begin{array}{c}1,1-D C A \\
(\mu \mathrm{g} / \mathrm{L})\end{array}$ & $\begin{array}{c}\text { CA } \\
(\mu \mathrm{g} / \mathrm{L})\end{array}$ & $\begin{array}{c}\text { 1,1-DCE } \\
(\mu \mathrm{g} / \mathrm{L})\end{array}$ & $\begin{array}{c}\text { Total } \\
\text { BTEX } \\
(\mu \mathrm{g} / \mathrm{L})\end{array}$ & $\begin{array}{l}\text { Total } \\
\text { CVOCs } \\
\text { ( } \mu \mathrm{g} / \mathrm{L})\end{array}$ \\
\hline \multicolumn{8}{|c|}{ Southern plantation-Continued } \\
\hline \multirow[t]{7}{*}{ P1-7 } & 06-08-99 & $<670$ & $<670$ & $<1,300$ & $<670$ & nd & 64,000 \\
\hline & $06-22-00$ & .24 & 17 & 8.4 & 72 & 18 & 75,000 \\
\hline & 06-14-01 & $<20$ & $<20$ & $<20$ & 44 & nd & 68,000 \\
\hline & 06-14-02 & $<20$ & 14 & $<20$ & 64 & nd & 105,000 \\
\hline & $06-20-03$ & $<2,000$ & $<2,000$ & $<4,000$ & $<2,000$ & nd & 69,000 \\
\hline & 06-18-04 & $<3,300$ & $<3,300$ & $<6,700$ & $<3,300$ & nd & 103,000 \\
\hline & $06-22-05$ & $<2,000$ & $<2,000$ & $<4,000$ & $<2,000$ & nd & 92,000 \\
\hline \multirow[t]{6}{*}{ P1-8 } & 06-07-99 & $<710$ & $<710$ & $<1,400$ & $<710$ & nd & 29,000 \\
\hline & 06-14-01 & $<20$ & $<20$ & $<20$ & $<20$ & nd & 14,000 \\
\hline & 06-13-02 & $<20$ & $<20$ & $<20$ & 16 & nd & 32,000 \\
\hline & $06-20-03$ & $<10$ & 4.2 & $<20$ & $<10$ & nd & 270 \\
\hline & 06-18-04 & $<1.0$ & $<1.0$ & $<2.0$ & $<1.0$ & nd & 20 \\
\hline & 06-23-05 & $<1.0$ & $<1.0$ & $<2.0$ & $<1.0$ & nd & 30 \\
\hline \multirow[t]{7}{*}{ P1-9 } & 06-08-99 & $<2,000$ & $<2,000$ & $<4,000$ & $<2,000$ & nd & 140,000 \\
\hline & $06-22-00$ & $<10$ & 2.6 & $<20$ & 47 & 36 & 160,000 \\
\hline & 06-14-01 & $<40$ & $<40$ & $<40$ & $<40$ & nd & 37,000 \\
\hline & 06-13-02 & $<20$ & $<20$ & $<20$ & 54 & 11 & 180,000 \\
\hline & 06-20-03 & $<1,000$ & $<1,000$ & $<2,000$ & $<1,000$ & nd & 89,000 \\
\hline & 06-18-04 & $<1,300$ & $<1,300$ & $<2,700$ & $<1,300$ & nd & 75,000 \\
\hline & $06-23-05$ & $<20$ & $<20$ & $<40$ & $<20$ & nd & 1,000 \\
\hline \multirow[t]{7}{*}{$\mathrm{P} 1-10$} & 06-07-99 & $<1,000$ & $<1,000$ & $<2,000$ & $<1,000$ & nd & 51,000 \\
\hline & $06-22-00$ & $<.1$ & 1.2 & .13 & 16 & 12 & 24,000 \\
\hline & 06-13-01 & $<20$ & $<20$ & $<20$ & 11 & nd & 21,000 \\
\hline & $06-12-02$ & $<20$ & $<20$ & $<20$ & $<20$ & nd & 14,000 \\
\hline & 06-19-03 & $<400$ & $<400$ & $<800$ & $<400$ & nd & 13,000 \\
\hline & 06-18-04 & $<200$ & $<200$ & $<400$ & $<200$ & nd & 6,500 \\
\hline & 06-23-05 & $<100$ & $<100$ & $<200$ & $<100$ & nd & 4,800 \\
\hline \multicolumn{8}{|c|}{ Intermediate aquifer } \\
\hline 1MW-4 & 06-17-04 & $<1.0$ & $<1.0$ & $<2.0$ & $<1.0$ & nd & nd \\
\hline \multirow[t]{4}{*}{ MW1-25 } & $06-14-02$ & $<20$ & $<20$ & $<20$ & $<20$ & nd & 2,400 \\
\hline & $06-19-03$ & $<67$ & $<67$ & $<130$ & $<67$ & nd & 2,100 \\
\hline & 06-06-04 & - & - & - & - & - & - \\
\hline & $06-21-05$ & $<67$ & $<67$ & $<130$ & $<67$ & nd & 2,000 \\
\hline \multirow[t]{4}{*}{ MW1-28 } & 06-14-02 & $<20$ & $<20$ & $<20$ & $<20$ & nd & 2,400 \\
\hline & $06-19-03$ & $<50$ & $<50$ & $<100$ & $<50$ & nd & 1,700 \\
\hline & $06-16-04$ & - & - & - & - & - & - \\
\hline & $06-21-05$ & $<67$ & $<67$ & $<130$ & $<67$ & nd & 2,300 \\
\hline \multirow[t]{3}{*}{ MW1-38 } & $06-12-02$ & $<.20$ & $<.20$ & $<.20$ & $<.20$ & nd & nd \\
\hline & $06-16-04$ & - & - & - & - & - & - \\
\hline & $06-21-05$ & $<1.0$ & $<1.0$ & $<2.0$ & $<1.0$ & nd & nd \\
\hline \multirow[t]{2}{*}{ MW1-39 } & $06-19-03$ & $<1.0$ & $<1.0$ & $<2.0$ & $<1.0$ & nd & 2.0 \\
\hline & $06-16-04$ & - & - & - & - & - & - \\
\hline
\end{tabular}


Table 3. Concentrations of selected volatile organic compounds in ground-water samples from monitoring wells, piezometers, and diffusion samplers, and in surface-water samples from the marsh stream collected by the USGS from 1999 to 2005 at Operable Unit 1, Naval Undersea Warfare Center, Division Keyport, Washington—Continued.

[All data except those shaded were published previously in Dinicola and others (2002), Dinicola (2003), Dinicola (2004), and Dinicola and Huffman (2004). Reported concentrations less than the detection limit are estimated. Laboratory data qualifier codes, such as " $D$ " for dilution, are not shown. Volatile organic compounds (VOCs); PCE, tetrachloroethene; TCE, trichloroethene; cis-DCE, cis-1,2-dichloroethene; trans-DCE, trans-1,2-dichloroethene; VC, vinyl chloride; 1,1,1-TCA, 1,1,1-trichloroethane; 1,1-DCA, 1,1-dichloroethane; CA, chloroethane; 1,1-DCE, 1,1-dichloroethene; total BTEX, sum of benzene, toluene, ethylbenzene, and xylene; total CVOCs, sum of chlorinated volatile organic compounds. Methane data are presented for diffusion samplers only. Abbreviations: E, estimated value; $\mu \mathrm{g} / \mathrm{L}$, microgram per liter; dup, duplicate; blank, field blank; <, actual value is less than value shown; nd, not detected; -, not analyzed]

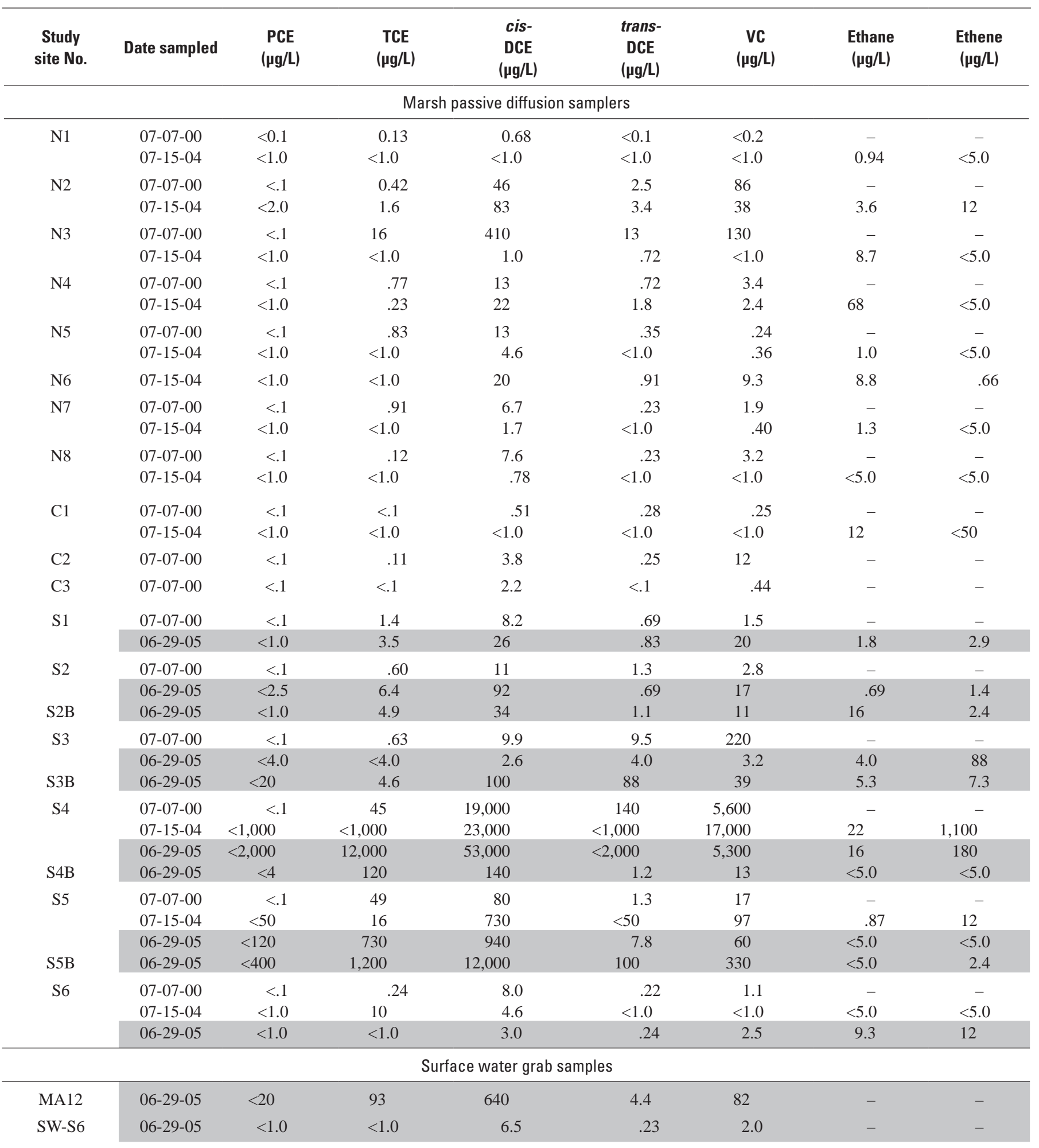


Table 3. Concentrations of selected volatile organic compounds in ground-water samples from monitoring wells, piezometers, and diffusion samplers, and in surface-water samples from the marsh stream collected by the USGS from 1999 to 2005 at Operable Unit 1, Naval Undersea Warfare Center, Division Keyport, Washington—Continued.

[All data except those shaded were published previously in Dinicola and others (2002), Dinicola (2003), Dinicola (2004), and Dinicola and Huffman (2004). Reported concentrations less than the detection limit are estimated. Laboratory data qualifier codes, such as " $\mathrm{D}$ " for dilution, are not shown. Volatile organic compounds (VOCs); PCE, tetrachloroethene; TCE, trichloroethene; cis-DCE, cis-1,2-dichloroethene; trans-DCE, trans-1,2-dichloroethene; VC, vinyl chloride; 1,1,1-TCA, 1,1,1-trichloroethane; 1,1-DCA, 1,1-dichloroethane; CA, chloroethane; 1,1-DCE, 1,1-dichloroethene; total BTEX, sum of benzene, toluene, ethylbenzene, and xylene; total CVOCs, sum of chlorinated volatile organic compounds. Methane data are presented for diffusion samplers only. Abbreviations: E, estimated value; $\mu \mathrm{g} / \mathrm{L}$, microgram per liter; dup, duplicate; blank, field blank; <, actual value is less than value shown; nd, not detected; -, not analyzed]

\begin{tabular}{|c|c|c|c|c|c|c|c|}
\hline $\begin{array}{c}\text { Study } \\
\text { site No. }\end{array}$ & Date sampled & $\begin{array}{c}1,1,1-T C A \\
(\mu \mathrm{g} / \mathrm{L})\end{array}$ & $\begin{array}{c}\text { 1,1-DCA } \\
(\mu \mathrm{g} / \mathrm{L})\end{array}$ & $\begin{array}{c}\text { CA } \\
(\mu \mathrm{g} / \mathrm{L})\end{array}$ & $\begin{array}{c}\text { 1,1-DCE } \\
(\mu \mathrm{g} / \mathrm{L})\end{array}$ & $\begin{array}{l}\text { Total } \\
\text { BTEX } \\
(\mu \mathrm{g} / \mathrm{L})\end{array}$ & $\begin{array}{l}\text { Total } \\
\text { CVOCs } \\
\text { ( } \mu \mathrm{g} / \mathrm{L})\end{array}$ \\
\hline \multicolumn{8}{|c|}{ Marsh passive diffusion samplers } \\
\hline N1 & $\begin{array}{l}07-07-00 \\
07-15-04\end{array}$ & $\begin{array}{l}<0.1 \\
<1.0\end{array}$ & $\begin{array}{l}<0.1 \\
<1.0\end{array}$ & $\begin{array}{c}- \\
<2.0\end{array}$ & $\begin{array}{l}<0.1 \\
<1.0\end{array}$ & $\begin{array}{l}\text { nd } \\
\text { nd }\end{array}$ & $\begin{array}{r}1 \\
\text { nd }\end{array}$ \\
\hline N2 & $\begin{array}{l}07-07-00 \\
07-15-04\end{array}$ & $\begin{array}{l}<.1 \\
<2.0\end{array}$ & $\begin{array}{r}1.61 \\
.76\end{array}$ & $\begin{array}{c}- \\
<4.0\end{array}$ & $\begin{array}{r}<.1 \\
<2.0\end{array}$ & $\begin{array}{l}0.57 \\
\text { nd }\end{array}$ & $\begin{array}{l}140 \\
130\end{array}$ \\
\hline N3 & $\begin{array}{l}07-07-00 \\
07-15-04\end{array}$ & $\begin{array}{l}<.1 \\
<1.0\end{array}$ & $\begin{array}{l}<.1 \\
<1.0\end{array}$ & $\begin{array}{c}- \\
<2.0\end{array}$ & $\begin{array}{r}1.2 \\
<1.0\end{array}$ & $\begin{array}{l}\text { nd } \\
.43\end{array}$ & $\begin{array}{r}570 \\
2\end{array}$ \\
\hline N4 & $\begin{array}{l}07-07-00 \\
07-15-04\end{array}$ & $\begin{array}{r}<.1 \\
<1.0\end{array}$ & $\begin{array}{r}<.1 \\
<1.0\end{array}$ & $\begin{array}{c}- \\
<2.0\end{array}$ & $\begin{array}{r}<.1 \\
<1.0\end{array}$ & $\begin{array}{l}.14 \\
1.1\end{array}$ & $\begin{array}{l}18 \\
26\end{array}$ \\
\hline N5 & $\begin{array}{l}07-07-00 \\
07-15-04\end{array}$ & $\begin{array}{r}<.1 \\
<1.0\end{array}$ & $\begin{array}{l}.22 \\
<1.0\end{array}$ & $\begin{array}{l}- \\
<2.0\end{array}$ & $\begin{array}{r}<.1 \\
<1.0\end{array}$ & $\begin{array}{l}.28 \\
\mathrm{nd}\end{array}$ & $\begin{array}{r}15 \\
5\end{array}$ \\
\hline N6 & $07-15-04$ & $<1.0$ & $<1.0$ & $<2.0$ & $<1.0$ & .25 & 30 \\
\hline N7 & $\begin{array}{l}07-07-00 \\
07-15-04\end{array}$ & $\begin{array}{l}<.1 \\
<1.0\end{array}$ & $\begin{array}{l}.15 \\
<1.0\end{array}$ & $\begin{array}{c}- \\
<2.0\end{array}$ & $\begin{array}{r}<.1 \\
<1.0\end{array}$ & $\begin{array}{l}.27 \\
\mathrm{nd}\end{array}$ & $\begin{array}{r}10 \\
2\end{array}$ \\
\hline N8 & $\begin{array}{l}07-07-00 \\
07-15-04\end{array}$ & $\begin{array}{l}<.1 \\
<1.0\end{array}$ & $\begin{array}{l}.12 \\
<1.0\end{array}$ & $\begin{array}{c}- \\
<2.0\end{array}$ & $\begin{array}{l}<.1 \\
<1.0\end{array}$ & $\begin{array}{c}.13 \\
\text { nd }\end{array}$ & $\begin{array}{r}11 \\
1\end{array}$ \\
\hline $\mathrm{C} 1$ & $\begin{array}{l}07-07-00 \\
07-15-04\end{array}$ & $\begin{array}{r}<.1 \\
<1.0\end{array}$ & $\begin{array}{r}<.1 \\
<1.0\end{array}$ & $\begin{array}{c}- \\
<2.0\end{array}$ & $\begin{array}{r}<.1 \\
<1.0\end{array}$ & $\begin{array}{l}1.4 \\
.71\end{array}$ & $\begin{array}{r}1 \\
\text { nd }\end{array}$ \\
\hline $\mathrm{C} 2$ & 07-07-00 & $<.1$ & .11 & - & $<.1$ & 2.7 & 16 \\
\hline $\mathrm{C} 3$ & $07-07-00$ & $<.1$ & $<.1$ & - & $<.1$ & nd & 3 \\
\hline $\mathrm{S} 1$ & $\begin{array}{l}07-07-00 \\
06-29-05\end{array}$ & $\begin{array}{r}<.1 \\
<1.0\end{array}$ & $\begin{array}{l}4.7 \\
3.6\end{array}$ & $\begin{array}{c}24 \\
3.7\end{array}$ & $\begin{array}{r}<.1 \\
<1.0\end{array}$ & $\begin{array}{l}2.6 \\
30\end{array}$ & $\begin{array}{l}40 \\
58\end{array}$ \\
\hline $\mathrm{S} 2 \mathrm{~B}$ & $\begin{array}{l}07-07-00 \\
06-29-05 \\
06-29-05\end{array}$ & $\begin{array}{l}<.1 \\
<2.5 \\
<1.0\end{array}$ & $\begin{array}{l}6.1 \\
2.5 \\
3.4\end{array}$ & $\begin{array}{l}10 \\
2.6 \\
6.1\end{array}$ & $\begin{array}{l}<.1 \\
<2.5 \\
<1.0\end{array}$ & $\begin{array}{c}2.6 \\
.53 \\
.94\end{array}$ & $\begin{array}{r}32 \\
120 \\
60\end{array}$ \\
\hline $\begin{array}{c}\text { S3 } \\
\text { S3B }\end{array}$ & $\begin{array}{l}07-07-00 \\
06-29-05 \\
06-29-05\end{array}$ & $\begin{array}{r}<.1 \\
<4.0 \\
<2.0\end{array}$ & $\begin{array}{c}460 \\
87 \\
2.1\end{array}$ & $\begin{array}{l}36 \\
29 \\
7.7\end{array}$ & $\begin{array}{r}<.1 \\
<4.0 \\
<2.0\end{array}$ & $\begin{array}{c}5.9 \\
\text { nd } \\
1.3\end{array}$ & $\begin{array}{l}730 \\
126 \\
150\end{array}$ \\
\hline S4B & $\begin{array}{l}07-07-00 \\
07-15-04 \\
06-29-05 \\
06-29-05\end{array}$ & $\begin{aligned} & <.1 \\
<1,000 & <2,000 \\
< & <0\end{aligned}$ & $\begin{array}{c}\quad .91 \\
<1,000 \\
<2,000 \\
<20\end{array}$ & $\begin{array}{r}20 \\
<2,000 \\
<4,000 \\
<40\end{array}$ & $\begin{array}{r}73 \\
<1,000 \\
<2,000 \\
<2.0\end{array}$ & $\begin{array}{l}5.1 \\
\text { nd } \\
\text { nd } \\
\text { nd }\end{array}$ & $\begin{array}{r}25,000 \\
40,000 \\
70,000 \\
270\end{array}$ \\
\hline S5B & $\begin{array}{l}07-07-00 \\
07-15-04 \\
06-29-05 \\
06-29-05\end{array}$ & $\begin{aligned} &<.1 \\
&<50<20 \\
&<400\end{aligned}$ & $\begin{aligned} &<.1 \\
&<50<20 \\
&<400\end{aligned}$ & $\begin{array}{r}- \\
<100 \\
<40 \\
<800\end{array}$ & $\begin{array}{l}\quad .17 \\
<50 \\
<20 \\
<400\end{array}$ & $\begin{array}{l}.15 \\
\text { nd } \\
\text { nd } \\
\text { nd }\end{array}$ & $\begin{array}{r}150 \\
840 \\
1,700 \\
14,000\end{array}$ \\
\hline S6 & $\begin{array}{l}07-07-00 \\
07-15-04 \\
06-29-05\end{array}$ & $\begin{array}{l}<.1 \\
<1.0 \\
<1.0\end{array}$ & $\begin{array}{r}<.1 \\
<1.0 \\
<1.0\end{array}$ & $\begin{array}{l}- \\
<2.0 \\
<2.0\end{array}$ & $\begin{array}{r}<.1 \\
<1.0 \\
<1.0\end{array}$ & $\begin{array}{l}.62 \\
\text { nd } \\
8.7\end{array}$ & $\begin{array}{r}10 \\
15 \\
6\end{array}$ \\
\hline \multicolumn{8}{|c|}{ Surface water grab samples } \\
\hline MA12 & 06-29-05 & $<20$ & 7.9 & $<40$ & $<20$ & nd & 830 \\
\hline SW-S6 & $06-29-05$ & $<1.0$ & $<1.0$ & $<2.0$ & $<1.0$ & 0.59 & 9 \\
\hline
\end{tabular}




\section{Appendix A. Quality Assurance and Control of U.S. Geological Survey 2005 Geochemical Sampling}

Quality assurance and control of geochemical sampling included collecting duplicate samples for selected redoxsensitive analytes and volatile organic compounds (VOCs) and analyzing a field blank sample for VOCs. Field blanks were collected by pumping VOC-free water through previously used and cleaned tubing to determine possible sampling contamination in samples collected at known contaminated wells only; new tubing was used to sample from wells that were known to be uncontaminated or slightly contaminated, and from piezometers sampled for the first time. Complete laboratory quality assurance and control data from SevernTrent Laboratories is on file in the USGS office in Tacoma, Washington.
Duplicate sample results compared favorably for all constituents (table A1). A duplicate sample was collected and analyzed for organic carbon, manganese, sulfate, and chloride for piezometers P1-9 and P1-3. The duplicate results for those constituents agreed within 16 percent. A duplicate sample was collected and analyzed for piezometers P1-3 and P1-9 and the CVOC concentrations agreed within 10 percent (table 3).

Chloroethenes, chloroethanes, and benzene, toluene, ethylbenze, and xylene (BTEX) were not detected in the field blank sample of pumped VOC-free water (site P1-9FB). No ethene, ethane, or chloroethene or choroethane compounds of interest were detected in laboratory method.

Table A1. Quality assurance data collected by the U.S. Geological Survey at Operable Unit 1, Naval Undersea Warfare Center, Division Keyport, Washington.

[Study site No.: D denotes duplicate sample; FB denotes field blank sample. Volatile organic compounds (VOCs): PCE, tetrachloroethene; TCE, trichloroethene; cis-DCE, cis-1,2-dichloroethene; trans-DCE, trans-1,2-dichloroethene; VC, vinyl chloride; TCA, 1,1-trichloroethane; 1,1-DCA,

1,1-dichloroethane, CA, chloroethane; BTEX, benzene, toluene, ethylbezene, and xylene; CVOCs, sum of all chloroethenes and chloroethane concentrations shown in table. Abbreviations: E, estimated value; $\mathrm{mg} / \mathrm{L}$, milligrams per liter; $\mu \mathrm{g} / \mathrm{L}$, micrograms per liter; nd, not detected. Symbols: <, actual value is less than the value shown; -, not analyzed]

\begin{tabular}{|c|c|c|c|c|c|c|c|c|c|c|c|c|}
\hline $\begin{array}{c}\text { Study } \\
\text { site No. }\end{array}$ & $\begin{array}{c}\text { Date } \\
\text { sampled }\end{array}$ & $\begin{array}{c}\text { PCE } \\
(\mu \mathrm{g} / \mathrm{L})\end{array}$ & $\begin{array}{c}\text { TCE } \\
(\mu \mathrm{g} / \mathrm{L})\end{array}$ & $\begin{array}{c}\text { cis-DCE } \\
(\mu \mathrm{g} / \mathrm{L})\end{array}$ & $\begin{array}{c}\text { trans-DCE } \\
(\mu \mathrm{g} / \mathrm{L})\end{array}$ & $\begin{array}{c}\text { VC } \\
(\mu \mathrm{g} / \mathrm{L})\end{array}$ & $\begin{array}{l}\text { Ethane } \\
(\mu \mathrm{g} / \mathrm{L})\end{array}$ & $\begin{array}{c}\text { Ethene } \\
(\mu \mathrm{g} / \mathrm{L})\end{array}$ & $\begin{array}{c}\text { TCA } \\
(\mu \mathrm{g} / \mathrm{L})\end{array}$ & $\begin{array}{c}\text { 1,1-DCA } \\
(\mu \mathrm{g} / \mathrm{L})\end{array}$ & $\begin{array}{c}\text { CA } \\
(\mu \mathrm{g} / \mathrm{L})\end{array}$ & $\begin{array}{c}\text { 1,1-DCE } \\
(\mu \mathrm{g} / \mathrm{L})\end{array}$ \\
\hline P1-3 & $06-22-05$ & $<1.0$ & $<1.0$ & 11 & 1.3 & 35 & 44 & 30 & $<1.0$ & 0.31 & 2.6 & $<1.0$ \\
\hline$P 1-3 D$ & $06-22-05$ & $<1.0$ & $<1.0$ & 9.9 & 1.2 & 33 & 38 & 27 & $<1.0$ & .34 & 2.7 & $<1.0$ \\
\hline P1-9 & 06-23-05 & $<20$ & 230 & 700 & E3.2 & 97 & $<5$ & 4 & $<20$ & $<20$ & $<40$ & $<20$ \\
\hline P1-9D & $06-23-05$ & $<20$ & 210 & 640 & 3.1 & 90 & $<5$ & 3.7 & $<20$ & $<20$ & $<40$ & $<20$ \\
\hline P1-9FB & $06-23-05$ & $<1.0$ & $<1.0$ & $<1.0$ & $<1.0$ & $<1.0$ & $<5$ & $<5$ & $<1.0$ & $<1.0$ & $<2.0$ & $<1.0$ \\
\hline
\end{tabular}

\begin{tabular}{|c|c|c|c|c|c|c|c|c|c|c|c|c|c|}
\hline $\begin{array}{c}\text { Study } \\
\text { site No. }\end{array}$ & $\begin{array}{c}\text { Date } \\
\text { sampled }\end{array}$ & \multicolumn{2}{|c|}{ Total } & $\begin{array}{c}\text { Dissolved } \\
\text { oxygen } \\
\text { (mg/L) }\end{array}$ & $\begin{array}{c}\text { Filtered } \\
\mathrm{NO}_{2}+\mathrm{NO}_{3} \\
(\mathrm{mg} / \mathrm{L})\end{array}$ & $\begin{array}{c}\text { Filtered } \\
\text { (dissolved) } \\
\text { organic } \\
\text { carbon } \\
\text { (mg/L) }\end{array}$ & $\begin{array}{c}\text { Filtered } \\
\text { manga- } \\
\text { nese } \\
\text { (mg/L) }\end{array}$ & $\begin{array}{c}\text { Filtered } \\
\text { iron (II) } \\
\text { (mg/L) }\end{array}$ & $\begin{array}{c}\text { Filtered } \\
\text { sulfate } \\
\text { (mg/L) }\end{array}$ & $\begin{array}{l}\text { Unfiltered } \\
\text { sulfide } \\
\text { (mg/L) }\end{array}$ & $\begin{array}{l}\text { Dissolved } \\
\text { methane } \\
\text { (mg/L) }\end{array}$ & $\begin{array}{c}\text { Dissolved } \\
\text { carbon } \\
\text { dioxide } \\
\text { (mg/L) }\end{array}$ & $\begin{array}{c}\text { Filtered } \\
\text { chloride } \\
\text { (mg/L) }\end{array}$ \\
\hline P1-3 & $06-22-05$ & 23 & 65 & $<0.1$ & - & 20 & 2.8 & - & 0.38 & 0.03 & 8.4 & 320 & 68 \\
\hline P1-3D & 06-22-05 & 23 & 61 & $<.1$ & - & 20 & 2.8 & - & .37 & .03 & - & - & 68 \\
\hline P1-9FB & 06-23-05 & nd & nd & - & $<0.06$ & - & $<.006$ & - & $<.2$ & - & $<5$ & - & $<.20$ \\
\hline
\end{tabular}


This page intentionally left blank. 
Manuscript approved for publication, December 7, 2006

Prepared by the USGS Publishing Network,

Publishing Service Center, Tacoma, Washington

Bill Gibbs

Debra Grillo

Sharon Wahlstrom

Bobbie Jo Richey

Publishing Service Center, Sacramento, California

Virginia Wenslaff

For more information concerning the research in this report, contact the

Washington Water Science Center Director,

U.S. Geological Survey, 934 Broadway — Suite 300

Tacoma, Washington 98402

http://wa.water.usgs.gov 


\section{$\mathbb{Z}$ 脸}

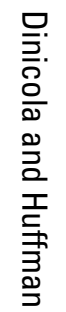

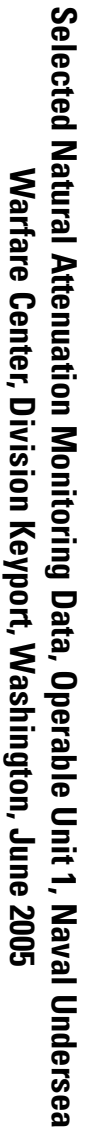

